\title{
COST OF BEING A MEXICAN IMMIGRANT AND BEING A MEXICAN NON - CITIZEN IN CALIFORNIA AND TEXAS
}

\author{
A Thesis \\ by \\ ISAO TAKEI \\ Submitted to the Office of Graduate Studies of \\ Texas A\&M University \\ in partial fulfillment of the requirements for the degree of \\ MASTER OF SCIENCE
}

August 2005

Major Subject: Sociology 


\title{
COST OF BEING A MEXICAN IMMIGRANT AND BEING A MEXICAN NON - CITIZEN IN CALIFORNIA AND TEXAS
}

\author{
A Thesis \\ by \\ ISAO TAKEI
}

\begin{abstract}
Submitted to the Office of Graduate Studies of
Texas A\&M University

in partial fulfillment of the requirements for the degree of

MASTER OF SCIENCE
\end{abstract}

\begin{abstract}
Approved by:
Chair of Committee, Rogelio Saenz

Committee Members, Don Albrecht

William Alex. McIntosh

Head of Department, Rogelio Saenz
\end{abstract}

August 2005

Major Subject: Sociology 


\begin{abstract}
Cost of Being a Mexican Immigrant and Being a Mexican Non-Citizen in California and
\end{abstract}

Texas. (August 2005)

Isao Takei, B.A., Nihon University;

M.A., Nihon University

Chair of Advisory Committee: Dr. Rogelio Saenz

The purpose of this thesis is to examine hourly wage differences across different groups of Mexican-origin workers. First, I assess the cost of foreign-born status by comparing the hourly wages of Mexican immigrant workers with those of native-born Mexican American workers. Second, I assess the cost of non-citizenship status by comparing the hourly wages of non-citizens with those of Mexican-born U.S. naturalized citizens. I also seek to determine if these costs are greater in California than in Texas. The data are drawn from the 2000 5\% Public Use Microdata Sample (PUMS) U.S. Census. The results from multiple linear regression analyses show that being an immigrant, particularly a non-citizen immigrant, is associated with lower hourly wages, especially in California. Thus, Mexicanorigin workers, especially those in California, bear dual costs for being foreign-born and not being naturalized citizens. Furthermore, I focus on length of U.S. residence to assess the social and economic impact of the different periods on the costs associated with foreign-born status. First, those who came to the United States before the IRCA of 1986 and a series of California propositions during the 1990s have higher hourly wages than those who arrived later, because of more stable labor market conditions and the effect of the duration of stay in 
the United States. Second, those who arrived during the last decade have much lower hourly wages because of their disadvantaged labor market contexts. 


\section{ACKNOWLEDGEMENTS}

My thanks go to the many persons who have supported me during the years. I would like to thank Dr. Rogelio Saenz, my committee chair, for his valuable advice and continuing support in my studies at Texas A\&M University. He definitely gave me solid perspectives on my Mexican demographic research. His support for my presentations at major sociological conferences became the base of this study, and extended my research skills in demography and labor market analyses. I also thank Dr. William Alex. McIntosh and Dr. Don Albrecht, my excellent committee members, for their insightful comments, guidance and support throughout the course of this study. Their important feedback and advice encouraged my future studies in demography and labor markets.

Thanks also to my friends and other professors. I thank Dr. Wesley R. Dean for offering me a research assistantship position in the spring and summer of 2005 . I learned various statistical analyses and survey methodology in the project. Dr. Jon P. Alston willingly worked with me for cultural studies during my three years of studies in Texas A\&M University. I would like to thank him for his time and efforts in publishing a journal article and a book with me. Among my friends in the United States, I offer special thanks to Jing Li for her generous help. I also thank Dr. Arthur Sakamoto, Professor in the Department of Sociology at the University of Texas at Austin, for his technical advice for my statistics questions. In Japan, Professor Saburo Sato, my former academic adviser of the College of International Relations in Nihon University, has been encouraging and supporting of my research for years with his broad knowledge and kindness. Finally, I want to say, "Thank you" to my parents Kazuji Takei and Etsuko Takei for their continuous support for twentyeight years. 


\section{TABLE OF CONTENTS}

\section{Page}

ABSTRACT. iii

ACKNOWLEDGEMENTS $\mathrm{V}$

TABLE OF CONTENTS vi

LIST OF FIGURES viii

LIST OF TABLES ix

\section{CHAPTER}

I INTRODUCTION

II LITERATURE REVIEW, THEORETICAL PERSPECTIVES AND HYPOTHESES

Theories of Ethnic Labor Markets ....................................................... 6

State Differences in Anti-Immigrant Policies and Sentiments .............. 9

Immigrant Status and Naturalization Status .................................. 12

Human Capital Perspective ................................................................. 14

Summary and Hypotheses............................................................. 17

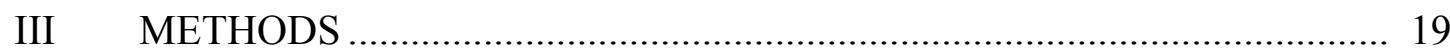

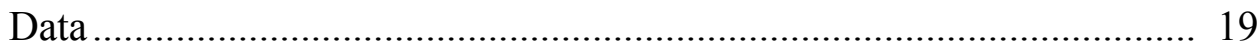

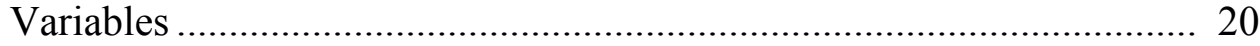

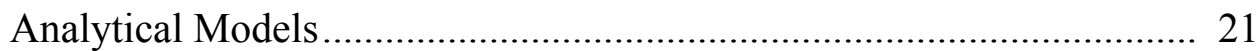

Statistical Procedures .................................................................... 24

Diagnostics......................................................................... 25

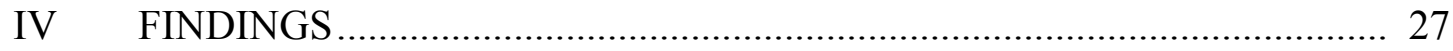

Descriptive Statistics.............................................................. 27

Cost of Being a Mexican Immigrant and Being a Mexican

Non-Citizen in California and Texas ................................................... 30

Length of U.S. Residence and the Cost of Being a Mexican

Immigrant and Non Citizen ........................................................ 42

Human Capital Attributes and Other Factors.................................... 47

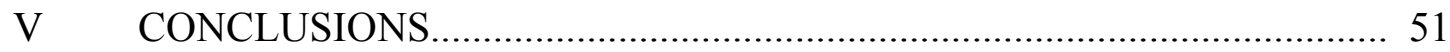




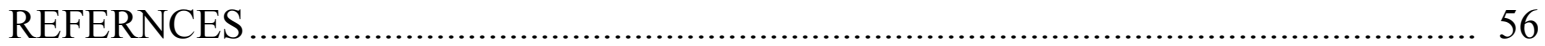

APPENDIX: INTERACTION EFFECTS …......................................................... 71

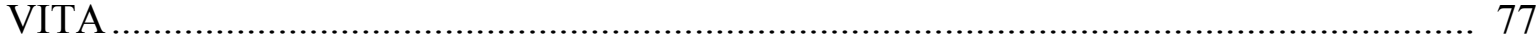




\section{LIST OF FIGURES}

FIGURE

Page

1 Native-Born, Foreign-Born, Citizen, and Non-Citizen.................................... 23

2 California Relative Wage Advantage Over Texas from OLS Regressions by Nativity and the U.S. Citizenship Status of the Foreign Born .............................. 39 


\section{LIST OF TABLES}

TABLE

Page

1 Measurement and Description of Dependent Variable and Independent Variables Used in the Analyses of Hourly Wage Differences among Persons of Mexican Origin in California and Texas, by 2000 5\% PUMS

2 Descriptive Statistics Based on Variables Used in the Analysis

3 The Cost of Being a Mexican Immigrant in California and Texas: Multiple Linear Regression Results for the Dependent Variable "the Natural Logarithm of the Hourly Wage"

4 The Cost of Being a Mexican Non-Citizen in California and Texas:

Multiple Linear Regression Results for the Dependent Variable "the Natural Logarithm of the Hourly Wage"

5 The Hourly Wage Difference of Native-Born Mexican American Workers in California and Texas: Multiple Linear Regression Results for the Dependent Variable "the Natural Logarithm of the Hourly Wage"

6 The Hourly Wage Difference of Foreign-Born Mexicans in California and Texas: Multiple Linear Regression Results for the Dependent Variable "the Natural Logarithm of the Hourly Wage"

7 The Hourly Wage Difference of Foreign-Born with Citizenship in California and Texas: Multiple Linear Regression Results for the Dependent Variable "the Natural Logarithm of the Hourly Wage"

8 The Hourly Wage Difference of Foreign-Born without Citizenship in California and Texas: Multiple Linear Regression Results for the Dependent Variable "the Natural Logarithm of the Hourly Wage"

9 Distribution of the Mexican-Origin Population Used in the Study Sample by Nativity and Period of Entry and Naturalization Status among the Foreign-Born by State.

10 The Cost of Being a Mexican Immigrant in California and Texas: Multiple Linear Regression Results for the Dependent Variable "the Natural Logarithm of the Hourly Wage":

With Length of U.S. Residence .... 
TABLE

11 The Cost of Being a Mexican Non - Citizen in California and Texas:

Multiple Linear Regression Results for the Dependent Variable

"the Natural Logarithm of the Hourly Wage":

Length of U.S. Residence Controlled ................................................................. 46

12 Selected Results of Interaction Tests ............................................................. 73 


\section{CHAPTER I}

\section{INTRODUCTION}

Due to its major growth, the Mexican-origin population has attracted much attention in labor market research (Chiswick, 1986). However, much of this research has been based on Mexican-Anglo comparisons (e.g., Bean et al., 1987; Borjas, 1983, 1983-1984, 1990, 1999; Borjas, 2000; Borjas and Freeman, 1992; Borjas and Tienda, 1987; Chapa, 1990; Chiswick, 1978; Frienberg and Hunt, 1995; Huddle, 1993; Kritz and Nogle, 1994; Marshall, 1984, 1987; Melendez et al., 1991; Simon et al., 1993; Talyor et al., 1988; Winegarden and Khor, 1991; Wright et al., 1997). Yet, this research approach is based on the aggregation of the entire Mexican-origin population, suggesting that the group is homogeneous.

For the comprehensive examination of the heterogeneity of Mexican-origin workers, the thesis focuses on internal hourly wage differences within this group. Among a number of human capital attributes, I focus on nativity status (native- and foreign-born) and immigrants' possession of U.S. citizenship (foreign-born with citizenship and non-citizen foreign-born status) as two core factors. Specifically, the thesis focuses on the cost of being an immigrant (the hourly wage differences between the native-born and the foreign-born) and the cost of being an immigrant without U.S. citizenship (the wage differences between naturalized immigrants and non-naturalized immigrants).

Demographic trends point to the increasing importance of Mexican immigrants in research on labor markets, especially those involving workers of Mexican origin. Indeed, among persons of Mexican origin, the foreign-born (96\%) increased nearly three times faster

The thesis follows the style of International Migration Review. 
than did the native-born (36\%) between 1990 and 2000 (Saenz, 2004a). Consequently, the share of the foreign-born in the Mexican-origin population rose from 36 percent in 1990 to 40 percent in 2000 (Saenz, 2004a).

Furthermore, foreign-born Mexicans have a significant attachment to the U.S. labor force. For instance, 71.4 percent of foreign-born males were in the labor force in 2000. However, they are especially likely to be in certain segments of the labor market. About $65 \%$ of the Mexican immigrant workers were employed in specific industrial niches, such as construction, farming, repair and maintenance, and manufacturing industries (Saenz, 2004a). The word "Latinoization of the U.S." denotes the disproportionate presence of Mexicans and other Latinos in selected occupations and industries. The waves of Mexican immigrants also include a small but steady increasing portion that have specialized skills (Alarcon, 1999; Castells, 1996; Clark, 1998; Keely, 1974; Kritz, 1987; Pellegrino, 2001; Roberts et al., 1999; Saxenian, 1996).

The majority of Mexican immigrants has historically been concentrated in the Southwest (Bean and Tienda, 1987; Durand et al., 2000), especially in California and Texas (Bustamante, 1997; Jargowsky, 1997; Massey, 1996; McCall, 2000a; Portes and Bach, 1980; Saenz, 1991; Stolzenberg, 1990). In these two primary destination states, large Spanishspeaking communities are well established (e.g., El Paso, Houston and San Antonio, TX and Los Angeles, San Francisco, San Ysidro and San Diego, CA) (Johnson and Oliver, 1989). Because of this large concentration, Clark (1998) points out that Los Angeles and Dallas have higher poverty rates for all immigrants than the U.S. as a whole. Kandel and Cromartie (2004) report that in the majority of southwestern counties, Latinos make up over 10 percent 
of the total population and continues to grow through a combination of high natural increase and net immigration.

Although both California and Texas continue to attract the majority of Mexican immigrants, these persons have encountered hasher treatment in California at least over the last decade. The Immigration Reform and Control Act (IRCA) of 1986 caused an expansion of the labor supply in the state; while the law was not particularly successful in reducing Mexican illegal migration to the U.S., about 2.3 million newly legalized Mexicans entered local labor markets (Durand et al., 2000). Due to a fear triggered by the massive growth of the immigrant population, mainly low-skilled undocumented Mexicans, California passed a series of anti-immigrant laws such as Proposition 198, 209, and 227 during the 1990s.

The passage of these welfare reform policies also represents social hostility that induced unfavorable treatment toward Mexican-origin workers in particular. The fiscal imperatives have directed their attention to Mexican migrant workers by unreasonably blaming them as "undeserving poor," because of their "culture of dependency," suggesting that they migrate to the U.S. to draw societal resources (Kurthen, 1997). Furthermore, as can be seen in Los Angeles riots of 1992, high population concentration of immigrants, especially undocumented immigrants, generated social unrest among the native-born who worried about rising crime rates (Sanchez, 1997).

It is likely that these harsh political and social contexts in California are translated to worse labor market outcomes for Mexican immigrants in California than in Texas. First, employer sanctions by IRCA and sentiments toward Mexicans have induced general discrimination against Mexican-origin workers in general (Davila et al., 1998). Second, after IRCA, Mexican immigrants faced wage penalties based on the absence of legal status 
(Donato and Massey, 1993; Philip and Massey, 1999; Sorensen and Bean, 1994). As greater concentration of immigrants is associated with lower hourly wage (Borjas, 1987a, 1987b, 1994, 1995; Tienda and Lii, 1987; Topel, 1994), hourly wages are expected to be lower in California than in Texas, all else equal.

The literature on anti-immigrant sentiments and laws in California remind us of the importance of considering not only nativity status and legal status of immigrants, but also non-economic factors (e.g., social and political contexts) for a comprehensive analysis of the labor market position of Mexicans. Therefore, to closely examine the state and local labor market characteristics, the thesis focuses on the hourly wage differences between California and Texas, instead of examining much broader social and economic contexts, such as comparing different standard Census regions (e.g., Midwest and West) and examining the entire country. I regard the word "labor market" as geographic areas beyond occupational and industrial categories to examine the impact of regional differences on wage.

Associated with the major factors mentioned above, another central element of the analysis is immigrants' length of U.S. residence. The literature suggests important links between the social and economic outcomes of immigrants and their temporal presence in this country. This focus gives the analyses of the costs associated with foreign-born status and a lack of U.S. citizenship a time dimension in considering variations across California and Texas with respect to the timing and volume of Mexican immigrants.

The data are drawn from the 2000 5\% Public Use Microdata Sample (PUMS). This study examines geographic differences in state-specific labor market contexts that are major determinants of wage (see Semyonov, 1988), comparing separate models of the two largest concentration states of Mexicans: California and Texas. 
This thesis contains five chapters. The first chapter presented here provides a brief introduction to the purpose and relevance of this study to the labor market research of Latinos/as, and discusses the value of this within-group wage analysis for a better understanding of the Mexican-origin population in the U.S.

Chapter II presents a detailed literature review and theoretical frameworks derived from past empirical and theoretical studies of ethnic labor markets and immigration. First, major labor market perspectives are reviewed, and the significance of examining nativity status and broad labor market contexts is emphasized. Second, I introduce the social and economic impacts of anti-immigrant sentiments and laws in California, and argue that the two largest concentration states of the Mexican-origin people in the Southwest, California and Texas, are associated with distinct labor market conditions that contribute to disparate labor market outcomes. Third, major individual-level attributes are introduced according to the human capital perspective. Based on the literature review, chapter II also summarizes theoretical approaches that are used in the analysis, and outlines the hypotheses drawn from theory.

Chapter III presents the methodology, data, variables, and statistical procedures used to conduct the analysis. Chapter IV presents the findings from the multiple linear regression models, and detailed discussions are given in line with the literature. Chapter V presents an overview of the findings, along with contribution of this study to Latino/a demography, public policy implications, strengths and limitations of this study, and provides a set of recommendations for future research. 


\section{CHAPTER II}

\section{LITERATURE REVIEW, THEORETICAL PERSPECTIVES AND HYPOTHESES}

As noted in chapter I, much of the research on wages involving Mexican-origin workers has been based on Mexican-Anglo wage differences. This research approach derives from labor market theories, which suggest that ethnic minorities tend to have comparatively fewer human capital resources and to receive lower returns to these resources than whites. Relatively little research has examined internal differentiation within the Mexican-origin population. This chapter is divided into five sections. In the literature review section, I first introduce the dual labor market and ethnic enclave economy theoretical perspectives, and point out that they do not sufficiently focus on both social context (e.g., regional differences) and individual differences (particularly native-/foreign-born status). Second, I introduce literature on anti-immigrant policies and sentiments in California during the last decades, to illustrate the fact that different groups of Mexican-origin workers faced variations in their environments which affect the opportunity structures of immigrants. Third, I provide a brief discussion of two key elements of the analysis - immigrant status and naturalization status. Fourth, major individual-level attributes related to wages, drawn from the human capital perspective, are introduced into the discussion. The last portion of the chapter presents a series of hypotheses drawn from the insights of the literature review and theoretical perspectives.

\section{Theories of Ethnic Labor Markets}

Theories of ethnic labor markets emphasize the economic structure associated with labor markets over human capital attributes in determining wages (Cornelius, 1981; Kalleberg and Sorensen, 1979; Portes and Bach, 1985; Portes and Truelove, 1987; Reed, 
2001; Sakamoto and Chen, 1991). A major prediction of the dual labor market theory (e.g., Bustamante, 1976; Edwards et al., 1975; Espenshade, 1995; Gordon, 1972; Kossoudji, 1989; Massey and Espinosa, 1997; Massey et al., 1993; Piore, 1979; Portes, 1981; Portes and Bach, 1980), for example, is that racial minorities and immigrants are disproportionately found in low-wage and unstable occupations identified with the secondary labor markets. ${ }^{1}$ Guided by the dual-system explanation of the U.S. labor market, past empirical studies have a strong tendency to aggregate Mexican-origin workers with different backgrounds as homogeneous, emphasizing their economic subordination in comparison to Anglos.

The ethnic enclave economy (e.g., the barrios of East Los Angeles, see Borjas, 1999), in contrast, suggests that immigrant and ethnic employees receive higher economic returns to their human capital resources as well as a range of non-monetary rewards (e.g., prospects of upward socioeconomic mobility) within mono-ethnic segmented labor markets (e.g., Bayer, 1968; Bonacich, 1972, 1973; Espenshade and King, 1994; Kossoudji, 1989; Light et al., 1994; Massey, 2001; Model, 1992; Nee and Sanders, 1987; Portes and Jensen, 1989, 1992; Sanders and Nee, 1987, 1992; Wilson and Martin, 1982; Zhou and Logan, 1989). For instance, a number of studies describe the relative strength of Mexican social networks for their employment compared to other minority groups (e.g., Bailey and Waldinger, 1991; Donato et al., 1992a; Enchautegui, 1998; Holzer, 1998; Gurak and Caces, 1992; Roberts et al., 1999).

However, these two theoretical approaches have some shortcomings (see Portes and Zhou, 1993). For example, researchers claim that the potential benefits of employment in ethnic enclaves are ambiguous because the perspective does not consider the relation of ethnic enclaves to the larger labor market and ignores workers engaged in this sector of the

\footnotetext{
${ }^{1}$ For Mexican immigrants' cases, see Bustamante (1976) and Portes and Bach (1980).
} 
economy (Massey et al., 1994; Reitz et al., 1981, cited in Roos and Hennessy, 1987; Tienda and Lii, 1987; Waldinger, 1986).

In their book titled The Latin Journey, Portes and Bach (1985) assert that there is no enclave economy for Mexican immigrants; instead Mexican immigrants participate as lowwage labor in the open economy. Wilson and Portes (1980) explain that the development of enclaves requires two conditions: first, the presence of immigrants with sufficient capital and initial entrepreneurial skills; and second, the renewal of the enclave labor force through a steady stream of new arrivals (also see Massey, 2001). ${ }^{2}$ The continuing influx of newcomers (Lien, 1994) due to the interconnectedness of the U.S. and Mexican economies (Massey and Espinosa, 1997) supports the second condition. However, as Mexican immigrants tend to have relatively limited human capital (Bean and Stevens, 2003; Cohen, 1989; Madhavan, 1985; Morales and Ong, 1993; Saenz, 1999; Tienda, 2002), the first condition is more tenuous in the case of Mexican immigrants. Nonetheless, Borjas (1999) observes the existence of Mexican ethnic enclaves.

Yet, ethnic labor market perspectives often ignore the following two important factors. First, these perspectives tend to ignore the differences between native- and foreign-born workers in the ethnic communities. Rather, labor market studies of Latinos/as focus on their collectivity, assuming that native- and foreign-born workers are connected in some way. Second, these perspectives do not necessarily consider the effect of broad social contexts (e.g., regional differences) on wages encompassing different types of labor markets (see Zucker and Rosenstein, 1981). Instead, their empirical evidence is limited to minority labor

\footnotetext{
${ }^{2}$ For further discussions of the ethnic enclave economy, see Bailey and Waldinger (1991) and Logan et al. (1994).
} 
market concentration in metropolitan areas and specific occupations, assuming that their status attainment is low.

Thus, much research has been conducted within a relatively limited scope of empirical questions, which inhibit the capturing of a large portrait of the diversity of the Mexican labor force. Accordingly, within-group wage differences between native- and foreign-born Mexican-origin workers have not yet been comprehensively analyzed (Bean et al., 1988; Bradshaw and Frisbie, 1983; Saenz, 2004b; Semyonov, 1988).

\section{State Differences in Anti-Immigrant Policies and Sentiments}

Kalleberg and Sorensen (1979) argue that "labor markets" can be used to denote geographic areas instead of occupational and industrial groups. Indeed, the description of the literature on the impact of regional differences on wages reminds us of the importance of considering the state and local labor market characteristics where people reside. This perspective enables us to better understand the different labor market situations of Mexicanorigin workers because such perspective also takes into account non-economic factors (e.g., social issues and politics) that often influence the economic outcomes of minority workers.

To closely examine the state and local labor market characteristics, the thesis focuses on hourly wage variations within Mexican-origin workers across California and Texas. In spite of the fact that both states continue to attract the majority of Mexican immigrants (Bean and Tienda, 1987; Bustamante, 1997; Clark, 1998; Durand et al., 2000; Jargowsky, 1997; Johnson and Oliver, 1989; Kandel and Cromartie, 2004; Massey, 1996; McCall, 2000a; Portes and Bach, 1980; Saenz, 1991; Stolzenberg, 1990), it is likely that variations in the strength of anti-immigrant policies and sentiments between California and Texas during the 
last decades resulted in different labor market conditions for Mexican-origin immigrants with those in California experiencing harsher conditions than their counterparts in Texas.

The Immigration Reform and Control Act (IRCA) of 1986 directly affected the economic situation of different groups of Mexican-origin workers (see Baker, 1997; Davila et al., 1998; Donato and Massey, 1993). ${ }^{3}$ IRCA for the first time made it illegal for employers to knowingly hire undocumented workers, imposing both civil and criminal penalties against those who did (Durand et al., 2000). Because of the disproportionate concentration of Mexican immigrants in the Southwest (especially in California and Texas), the impact of IRCA was especially obvious in this region.

Although IRCA was intended to reduce the number of undocumented migrants, it did not accomplish this goal. Indeed, research suggests that IRCA was not particularly successful in reducing Mexican illegal migration to the United States (Baker, 1997; Donato and Massey, 1993; Donato et al., 1992b); most employers mainly continued to hire undocumented migrants at lowered wages through increasing subcontract arrangements. ${ }^{4}$ Yet, IRCA did have other consequences. For example, about 2.3 million Mexicans acquired legal documents through IRCA, allowing many to enter the larger traditional labor market (Donato et al., 1992a; Durand et al., 2000; Philip and Massey, 1999; Valdes, 1995). In addition, employer sanctions induced general discrimination against undocumented-appearing Mexican-origin workers, including U.S.-born workers (Davila et al., 1998).

\footnotetext{
${ }^{3}$ Philip and Massey (1999) explain that IRCA sought to control undocumented immigration from Mexico by (1) sanctions against employers who knowingly hired undocumented migrants; (2) additional resources for the U.S. border patrol; and (3) authorizing amnesty for undocumented migrants who could prove continuous residence in the United States after January 1, 1982.

${ }^{4}$ Although the number arrested by the Immigration and Naturalization Service (INS) declined between 1986 and 1989, it surpassed pre-IRCA figures in 1990 (Williams, 1991; cited in Valdes, 1995).
} 
Many studies have examined IRCA's effects on the economic outcomes of Mexicanorigin workers, mostly the immigrant population (Davila et al., 1998; Philip and Massey, 1999; Sorensen and Bean, 1994). Such research has indicated that IRCA resulted in wage penalties against workers with undocumented status (Davila et al., 1998; Donato and Massey, 1993; Donato et al., 1992a); ${ }^{5}$ some undocumented migrants worked fewer hours after 1986 because of limited opportunities (Donato et al., 1992a), while others increased their work effort in order to compensate for the new shortfall in wages (Davila et al., 1998). The wage penalty for being undocumented suggests that there is a reward for being a legalized immigrant. In fact, research by Aguilera (2004) shows that Mexicans who became legal through IRCA experienced upward mobility. ${ }^{6}$

In the post-IRCA period, the effect of human capital (e.g., occupation and the duration of trips to the U.S.) declined in determining wages of both legal and undocumented migrants (Philip and Massey, 1999), with legal status becoming the primary determinant of wage rates (Donato and Massey, 1993). More specifically, Massey (1987) found that before IRCA, legal status had no effect on wage rates among Mexican migrants once selectivity and background differences between documented and undocumented migrants were controlled. Among both legal and undocumented migrants, wage rates tended to increase with rising age, education, labor force experience, U.S. migrant experience, and length of stay, and being urban origin migrants and nonagricultural workers (Massey, 1987b). These factors become less important determinants of wages compared to legal status following the implementation of IRCA.

\footnotetext{
${ }^{5}$ After IRCA, undocumented migrants working in the nonagricultural sector earned wages that were $22 \%$ lower than those earned by documented migrants with similar characteristics, and those working in the agricultural sector earned an additional 33\% less (Philip and Massey, 1999).

${ }^{6}$ However, Philip and Massey (1999) and Sorensen and Bean (1994) argue that IRCA adversely affected the wages of legal immigrants.
} 
Although IRCA is a federal law, Mexican immigrant workers in California might have faced harsher labor market conditions than their counterparts in Texas, due to a greater concentration of Mexican immigrants in California. Indeed, California initiatives such as Propositions 187, 209 and $227^{7}$ represent societal reactions and fears related to the perceived social and economic costs associated with the increasing presence of immigrants, mainly low-skilled undocumented Mexicans (Kurthen, 1997; Martin, 1995; Tolbert and Hero, 1996). ${ }^{8}$ The fiscal imperatives have directed their attention to Mexican migrant workers who are often labeled as the "undeserving poor" because of their so-called "culture of dependency" (Kurthen, 1997). Moreover, as can be seen in the Los Angeles riots of 1992, a number of new immigrants were involved in social unrest which escalated worries about rising crime rates (Sanchez, 1997).

The passage of anti-immigrant policies and hostility suggest that the costs associated with foreign-born status and the lack of naturalized status are greater in California than in Texas. However, it is important to examine the broader human capital literature to obtain a more expansive view of the factors that affect the labor market earnings of Mexican immigrants.

\section{Immigrant Status and Naturalization Status}

Past research shows that for individuals, immigrant status is a key factor affecting their wages (Chiswick, 1978; Cohen, 1989; Enchautegui, 1998; Heer, 1990; Madhavan,

\footnotetext{
${ }^{7}$ Proposition 187 in 1994 blocked the access of illegal immigrants to public education (from kindergarten through university), welfare, and non-emergency health care services. Proposition 209 in 1996 eliminated affirmative action programs. Proposition 227 in 1998 officially abolished bilingual education programs in public schools, as public education is the most costly service used by illegal aliens in California (Martin, 1995). For detailed explanations of these propositions, see Purcell (1997) and Tolbert and Hero (1996).

${ }^{8}$ Borjas (1999) argues that more recent immigrant waves are also more likely to use welfare than earlier waves. Borjas (1999:12) notes, for example, that "a comprehensive study by the National Academy of Sciences concluded that immigration raised the annual taxes of the typical native household in California by about $\$ 1,200$ a year."
} 
1985; Meisenheimer, 1992; Schoeni, 1998; Sehgal, 1985). In fact, Mexican immigrants in the United States, whether legal or undocumented, tend to have lower wages than U.S.-born Mexican Americans (Chiswick, 1986; Saenz, 2004b). Moreover, naturalization status well reflects immigrants' labor market values. Thus, the rate at which an immigrant group acquires citizenship is important (Portes and Mozo, 1985). However, data from the $20005 \%$ PUMS show that only 22.5 percent of Mexican immigrants are naturalized, compared to 30.2 percent of other immigrants from Latin America. The Mexican's low naturalization rate suggests that foreign-born Mexican workers face more wage disadvantages than native-born Mexican American workers. ${ }^{9}$ Another major reason accounting for immigrants' disadvantageous position is that human capital acquired outside the United States is imperfectly remunerated in the U.S. labor market (Borjas, 1999; Chiswick, 1978; Chiswick et al., 1997; Massey and Espinosa, 1997; Smith, 1984).

The disadvantage of being an immigrant varies by length of U.S. residence. In the short run, immigrants earn significantly less than native-born workers (Kossoudji, 1989). In all industrialized countries, there is apparently a tendency for citizens to be less willing to take certain menial and low-status jobs as economies advance (Marshall, 1984; Massey et al., 1994). Thus, immigrants compensate for their lower wages by putting more working hours with their strong motivation to work (Dominguez and Fernandez de Castro, 2001). ${ }^{10}$

However, immigrants generally improve their wage returns to their human capital with increasing length of stay in this country (see Chiswick, 1986, 1978; Chiswick et al.,

\footnotetext{
${ }^{9}$ Baker (1996:465) reports that "in 1994, nearly $40 \%$ of the Latino population in the United States was foreignborn, and only $18 \%$ of that foreign-born population had naturalized." This argument is supported by the potential "reversibility" of migration; immigrants who are difficult to return tend to naturalize at higher rates than those for whom return easily (Jasso and Rosenzweig, 1985, Portes and Mozo, 1985; cited in Portes and Truelove, 1987).

${ }^{10}$ Chiswick (1978) argues that for the same schooling, age, and other demographic characteristics immigrants to the U.S. have more ability relevant to the labor market than native-born persons.
} 
1997; Jensen, 1988; Simon and Sullivan, 1988; Tienda, 1983), although Borjas and Tienda (1993) argue that the disadvantages of undocumented relative to documented immigrants increase with age. With increasing time in the United States, Mexican immigrants have higher rates of English fluency, higher levels of education, higher presence in higher-status occupations, higher labor market wages, and lower poverty rates (Saenz, 2004a). In turn, these socioeconomic improvements increase the likelihood of naturalization (Liang, 1994). It is expected that all else equal, the costs associated with immigrant status and nonnaturalization status are greater in California than in Texas due to the larger concentration of immigrants (Borjas, 1987a, 1987b, 1994, 1995; Tienda and Lii, 1987; Topel, 1994) and more recent immigrants in California.

\section{Human Capital Perspective}

In order to assess the wage differences between native- and foreign-born Mexicanorigin workers, this study incorporates human capital factors into the analysis. The human capital perspective emphasizes that humans invest in the accumulation of human capital resources to maximize their labor market earnings (Becker, 1962, 1975; Borjas, 1983, 19831984; Cain, 1975; Chavez, 1991; Enchautegui, 1998; Espenshade, 1995; Kossoudji, 1989; Lee, 1966; Massey, 1987a, 1987b; Mincer, 1974; Schultz, 1961; Tickamyer and Bokemeier, 1993; Trejo, 1997). Moreover, it is suggested that the levels of human capital significantly differ by nativity status. In the following section, I briefly introduce selected human capital factors and note the major differences between the Mexican foreign-born and native-born with respect to human capital levels.

\section{Educational Attainment}

It is generally agreed that education provides a means for upward socioeconomic 
mobility (Becker, 1975; Borjas, 1999; Lacy et al., 1989; Ruiz-Quintanilla and Claes, 1996).

Educational attainment is an important investment because this is the base of other human capital factors such as specific vocational training (Massey, 1987b; Mincer, 1974), on-the-job experience and occupational skills (Juhn et al., 1993; Kalleberg and Sorensen, 1979; Oi, 1962). ${ }^{11}$ Further, as a result of technological changes, specialized skills are thought to be rewarded with higher wages, even among workers with the same education (e.g., Chiswick et al., 1997; Nonini and Ong, 1997; McCall, 2000a).

However, past research demonstrates that educational attainment has a weaker impact on the labor market outcomes of immigrants compared to the native-born, suggesting that pre-immigration skills are less relevant in the U.S. labor market than are the skills acquired by the native-born (Chiswick et al., 1997). Furthermore, Borjas (1999) argues that recent immigrants who arrived during the 1990s remain economically disadvantaged due to a lack of education, and he asserts that they reduce the wages of natives who compete with immigrant workers. Considering that foreign-born Mexicans tend have fewer years of formal schooling than native-born Mexican Americans (Chiswick, 1986), differences in education could be a key factor associated with the within-group wage gap.

Age

Age is also an important form of human capital (see Freeman, 1979; Hughes and Hutchinson, 1988; Jolly et al., 1978; Osberg et al., 1986; Pissarides and Wadsworth, 1990; Rones, 1983). Thus, Joll et al. (1991) point out that younger workers tend to have lower pay and higher labor market turnover rates compared to older workers. Youth unemployment is accordingly a common problem across different racial and ethnic groups (Borowski, 1984;

\footnotetext{
${ }^{11}$ Although they differ in their effects on earnings, in the amounts typically invested, in the size of returns, and in the extent to which the connection between investment and return is perceived, all these investments help improve skills, and thereby contribute to raising earnings (Becker, 1975).
} 
Brown and Sessions, 1997). ${ }^{12}$ In general, unemployed workers who enter the labor market at an early age tend to be less educated, inexperienced, and lack enough networks to locate and secure jobs compared to older workers (Clogg and Shockey, 1985; Lacy et al., 1989). Further, search theory assumes that relatively inexperienced younger workers, trying to find their most preferred match, are more likely to engage in voluntary unemployment as well as "jobhopping" than their older counterparts (Layard et al., 1991). The relative youthfulness of Mexican immigrants compared to native-born Mexican Americans (Chiswick, 1986) suggests that the foreign-born workers face higher risk of unemployment and lower wages than their native-born counterparts.

\section{English Language Proficiency}

English language proficiency is a crucial step in the broader process of economic mobility, and this human capital factor is strongly and positively related to earnings (see Chavez, 1991; Davila and Mora, 2000; Espinosa and Massey, 1997; Jasso and Rosenzweig, 1990; Massey, 1987a; McConnell and Leclere, 2002). Borjas (1999) notes that Latino immigrants who speak English earn 17 percent more than those who do not, even after adjusting for differences in education and other socioeconomic characteristics between the two groups. The degree of English language acquisition is a good indicator of acculturation, and linguistic isolation denotes lack of interaction outside the ethnic community (Stevens, 1992).

Researchers report that the majority of Mexican immigrants are monolingual Spanish speakers (Chiswick, 1986; Moore and Pachon, 1985; Saenz and Morales, 2005). This result is, in part, due to the large presence of recent immigrants among the Mexican foreign-born

\footnotetext{
${ }^{12}$ In the U.S., less than half of the total pool of 16- to 19-year-old high school dropouts and graduates not going to college held full-time jobs in October 1988 (Lacy and Heffeman, 1989).
} 
population (Saenz, 2004b). On the other hand, data from the $20005 \%$ PUMS show that the majority of native-born Mexican Americans speak English.

\section{Additional Control Variables}

Aside from human capital variables, other control factors are introduced into the analysis - metropolitan/nonmetropolitan residence, occupational categories and selfemployment status. Nonmetropolitan area residents tend to have lower hourly wages because of limited employment and occupational choices (Saenz and Torres, 2003). Although Mexican immigrants are disproportionately found in the low-skilled and low-wage labor force (Espenshade and Goodis, 1985; Massey and Schnabel, 1983; Portes and Truelove, 1987; Roos and Hennessy, 1987; Saenz and Torres, 2003; Waldinger, 1989a, 1989b, 1994), recent Mexican immigrants include a relatively small portion that have specialized skills (Alarcon, 1999; Castells, 1996; Clark, 1998; Keely, 1974; Kritz, 1987; Pellegrino, 2001; Roberts et al., 1999). Thus, there seems to be a large wage gap between the professional and non-professional occupational categories. Although self-employment is a classical form of labor force participation for ethnic minorities and immigrants (see Borjas, 1986; Fairlie and Meyer, 1996; Sanders and Nee, 1996; Spencer and Bean, 1999), Mexicans have relatively low self-employment rates (Saenz and Torres, 2003) because their self-employment is disadvantage-based, with a lack of large financial investment in a business and related resources (Borjas, 1986; Spencer and Bean, 1999).

\section{Summary and Hypotheses}

As Kalleberg and Sorensen (1979) argue that annual earnings and wage rates are the most easily quantified job rewards, this thesis seeks to assess internal hourly wage differences within the Mexican-origin workers for a better understanding of their 
heterogeneity. I draw on the literature and theoretical perspectives discussed above to develop a more comprehensive understanding of the labor market outcomes of Mexican immigrants in the key states of California and Texas. In particular, the thesis seeks to assess the extent to which the association between wages and immigration status/citizenship status among persons of Mexican-origin varies across California and Texas. Put simply, I investigate the cost of being a Mexican immigrant, or the hourly wage differences between the native-born and foreign-born, in California and Texas. In addition, among the foreignborn, I estimate the cost of being a Mexican immigrant without U.S. citizenship, or the wage differences between naturalized immigrants and non-naturalized immigrants, in the two states.

The thesis examines two sets of hypotheses. First, the following two major hypotheses regarding the costs associated with foreign-born status and the lack of naturalized status are examined.

$\mathrm{H}_{1}$ : Foreign-born persons of Mexican-origin have lower hourly wages than native-born Mexican Americans across both states (cost of being an immigrant).

$\mathrm{H}_{2}$ : Among foreign-born Mexican workers, those who are not naturalized U.S. citizens have lower hourly wages than U.S. naturalized citizens across both states (cost of being an immigrant non-citizen).

Second, following the literature on the impact of the California social and economic context (established anti-immigrant hostility and laws) on Mexican-origin workers' wages, the above two hypotheses are further specified as follows:

$\mathrm{H}_{3}$ : The cost of being an immigrant is higher in California than in Texas.

$\mathrm{H}_{4}$ : The cost of being a non-citizen is higher in California than in Texas. 


\section{CHAPTER III}

\section{METHODS}

The hypotheses outlined in the previous chapter are examined using data from the 2000 5\% Public-Use Microdata Sample (PUMS). This chapter presents an overview of the methodology used to conduct the analysis. The chapter discusses the data set, operationalization of the variables used in the analysis, analytical models, and the statistical procedures used to conduct the analysis.

\section{Data}

The data used in the analysis are drawn from the 2000 5-Percent PUMS. The PUMS has state-level Census 2000 data containing individual records for a five percent sample of people and housing units. The PUMS is widely used in earnings studies as it provides a large, nationally representative sample of all sectors of the labor force. The PUMS also ensures adequate sample sizes for the minority populations.

The population from which I draw my sample is persons of Mexican origin (both native- and foreign-born) living in California and Texas at the time of the census. The samples of California and Texas have a total of 221,366 Mexican-origin residents: California, 140,381; and Texas, 80,985 . There are a total of 119,740 immigrants in the sample: 84,447 in California; and 35,293 in Texas. Only persons of Mexican origin who worked at least 1,040 hours in 1999 are included in the sample. This restriction ensures that only workers that are attached to the labor force are included in the analysis. Note that persons who worked 1,040 hours in 1999 include full-time workers who were employed half the year as well as halftime workers who were employed year-round. The hourly wage is used instead of the annual 
wage income to account for the varying hours that people worked over the course of 1999. Analyses are restricted to individuals within the prime working age range from 16 to 64 .

\section{Variables}

The dependent variable is the natural logarithm of the hourly wage based on earnings in 1999. This transformation procedure is used to minimize the effect of outliers. Because I use the natural logarithm of wages, the coefficients can be interpreted as the percentage change in hourly wages, given a one-unit change in the independent variable. A detailed discussion about the natural logarithm and the logarithmic transformation is presented below.

The first independent variable imm measures immigrant status (foreign-born versus native-born status), scored "1" if the person is foreign-born (including both U.S. citizen by naturalization and non-citizen of the United States), and scored "0" if the person is U.S.-born. The construction of this variable allows for the assessment of "the cost of being a foreignborn Mexican," which is the heart of the analysis. The second independent variable nocit measures the immigrants' citizenship status, coded "1" if the person is not a naturalized citizen of the United States, and " 0 " if the person is a U.S. citizen by naturalization. This particular variable allows for the estimation of "the cost of not being a naturalized citizen," which is another major interest of the analysis.

Furthermore, for the analysis of the immigrants' duration of U.S. residence, the immigrant population is partitioned into four cohorts: arrivals in 1990-2000, arrivals in 19801989, arrivals in 1970-1979, and immigrants who arrived prior to 1970. Namely, the variable imm is replaced with four years-since-migration dummy variables (imm0069, imm7079, imm8089, and imm9000) using the variable YR2US (Year of Entry to United States) in the PUMS. 
Several control variables are used in the analysis. These include four human capital variables (age, sex, education, and self-reported English-language ability), one residential area variable (metropolitan/nonmetropolitan residence), and two variables based on occupation and self-employment status. The measurement and description of the dependent variable and the independent variables are presented in Table 1.

\section{Analytical Models}

The independent, control, and dependent variables are analyzed using an Ordinary Least Square (OLS) multiple linear regression model due to the interval-level dependent variable. The first two state-specific models (1A for California and 1B for Texas) investigate the cost of being a Mexican immigrant, that is, the hourly wage differences between the native-born and the foreign-born. The second set of models (2A for California and $2 \mathrm{~B}$ for Texas), based solely on the foreign-born population, analyzes the cost of being a Mexican immigrant without U.S. citizenship, that is, the wage differences between naturalized immigrants and non-naturalized immigrants (see Figure 1). ${ }^{13}$

The third set of models (Model 3A for California and Model 3B for Texas) assesses the costs associated with foreign-born status in terms of the four different periods in which immigrants came to the United States. The fourth set of models (Model 4A for California and Model 4B for Texas) estimates the cost associated with the lack of naturalized status controlling for immigrants' length of U.S. residence. The focus on immigrants' length of U.S. residence in models 3 and 4 will allow us to assess the extent to which the initial results (models 1 and 2) hold when length of U.S. residence is taken into account.

\footnotetext{
${ }^{13}$ I refer to the PUMS definition of "citizen" to categorize immigrant or non-immigrant (see Data Dictionary (5Percent), 7-54, U.S. Census Bureau, Census 2000).
} 
Table 1. Measurement and Description of Dependent Variable and Independent Variables Used in the Analyses of Hourly Wage Differences among Persons of Mexican Origin in California and Texas, by $20005 \%$ PUMS

\begin{tabular}{|c|c|}
\hline Variable Names & Measurement and Description of Variables or Categories \\
\hline $\begin{array}{l}\text { Dependent Variable } \\
\text { Lghrwage }\end{array}$ & Natural logarithm of hourly wages $=\log ($ annual income/the total working hours in year 1999) \\
\hline \multicolumn{2}{|c|}{ Independent Variables } \\
\hline Age & Numerical Variable; Age Range: 16-64 \\
\hline Male & Dummy Variable; Male $=1 ; \quad$ Female $=0$ \\
\hline Engabil & Dummy Variable; Speak English $=1$; does not Speak English $=0$ \\
\hline Metrores & Dummy Variable; Living in a Metropolitan Area $=1$; Not Living in a Metropolitan Area $=0$ \\
\hline $\mathrm{Imm}$ & Dummy Variable; Immigrant $=1$; Nonimmigrant $=0$ \\
\hline \multicolumn{2}{|c|}{ Length of U.S. residence for native-born and foreign-born comparison } \\
\hline $\operatorname{Imm} 0069$ & Dummy Variable; Foreign-Born Came to the U.S. before $1970=1$; otherwise $=0$ \\
\hline $\operatorname{Imm} 7079$ & Dummy Variable; Foreign-Born Came to the U.S. between 1970 and $1979=1$; otherwise $=0$ \\
\hline $\operatorname{Imm} 8089$ & Dummy Variable; Foreign-Born Came to the U.S. between 1980 and $1989=1$; otherwise $=0$ \\
\hline $\operatorname{Imm} 9000$ & Dummy Variable; Foreign-Born Came to the U.S. between 1990 and $2000=1$; otherwise $=0$ \\
\hline \multicolumn{2}{|c|}{ (Reference Group=Native-Born) } \\
\hline Noncit & Dummy Variable; Not a U.S. Citizen $=1$; U.S. Citizen by Naturalization $=0$ \\
\hline \multicolumn{2}{|l|}{ Educational Attainment } \\
\hline Somehs & Dummy Variable; Some High School but no Diploma $=1$; otherwise $=0$ \\
\hline Hsgrad & Dummy Variable; High School Graduate $=1$; otherwise $=0$ \\
\hline Somecoll & Dummy Variable; Some College but no Degree $=1$; otherwise $=0$ \\
\hline $\begin{array}{l}\text { Collgrad } \\
\text { (Reference Group }=\end{array}$ & $\begin{array}{l}\text { Dummy Variable; College Graduate }=1 \text {; otherwise }=0 \\
\text { dle School) }\end{array}$ \\
\hline \multicolumn{2}{|l|}{ Occupation } \\
\hline Mgrprorl & Dummy Variable; Management, Professional and Related Occupations $=1$; otherwise $=0$ \\
\hline Service & Dummy Variable; Service Occupations $=1$; otherwise $=0$ \\
\hline Salesoff & Dummy Variable; Sales and Office Occupations $=1$; otherwise $=0$ \\
\hline Cnstexmn & Dummy Variable; Construction, Extraction, and Maintenance Occupations $=1$; otherwise $=0$ \\
\hline $\begin{array}{l}\text { Prtrmtmv } \\
\text { (Reference Group }=\end{array}$ & $\begin{array}{l}\text { Dummy Variable; Production, Transportation, and Material Moving Occupations }=1 \text {; otherwise }=0 \\
\text { Fishing, and Forestry Occupations) }\end{array}$ \\
\hline Selfemp & Dummy Variable; Selfemployed $=1$; Not Selfemployed $=0$ \\
\hline
\end{tabular}


Figure 1: Native-Born, Foreign-Born, Citizen, and Non-Citizen

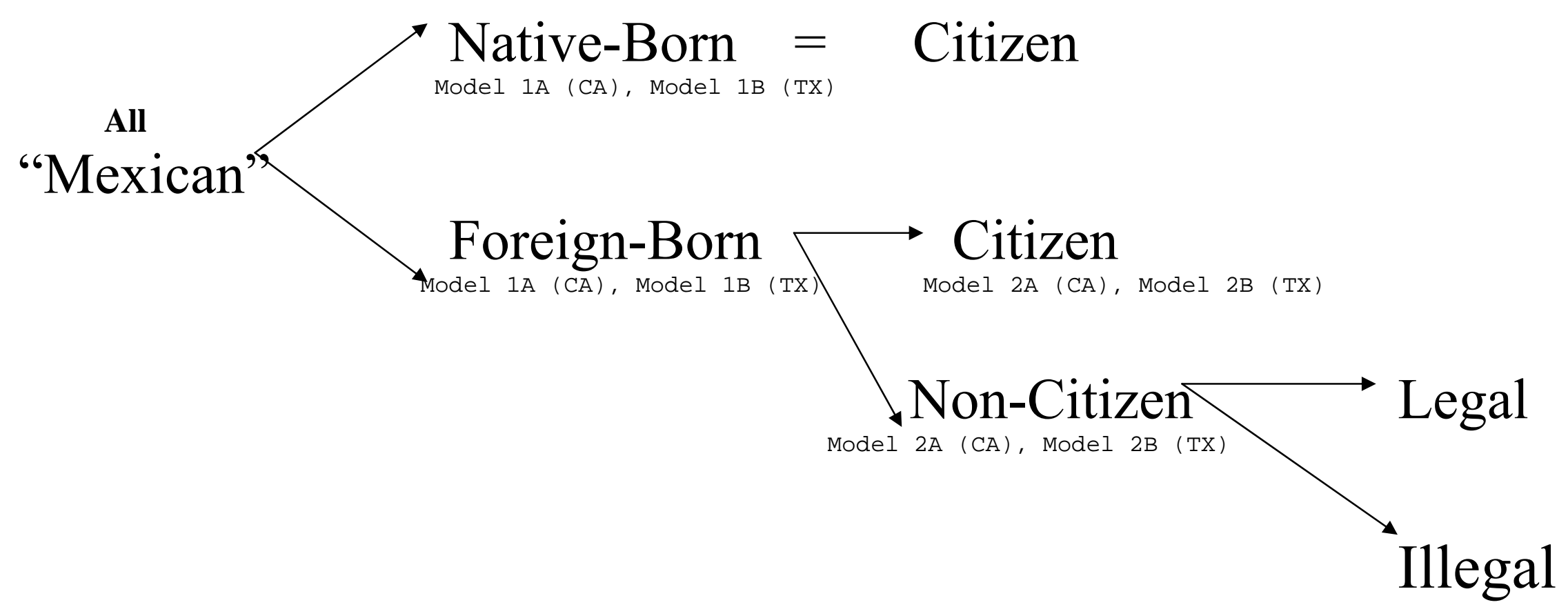


The thesis also analyzes other individual-level determinants of wage differences that are included in the models as controlled variables. For example, reflecting the recent major industrial changes associated with labor market situations of Mexican-origin workers (e.g., polarization of wages from middle-wage to low-or high-wage jobs), the effects of education and professional occupational categories on wages would show significant impacts on hourly wage gaps. Suggestions and discussions of other control variables are also given within the scope of the analysis.

\section{Statistical Procedures}

In this section I explain the statistical reasoning in the background of the natural logarithm and the logarithmic transformation. The natural logarithm of hourly wage is one of the most widely used dependent variables in the statistical analyses of labor market earnings (e.g., Donato and Massey, 1993; Portes and Zhou, 1996; Philip and Massey, 1999; Sakamoto et al., 2000; Tienda, 1983) because (1) hourly wage is highly skewed, and (2) a very useful multiplicative interpretation emerges in terms of the ratio of population medians (Ramsey and Schafer, 1997). Logged data tend to minimize the influence of the extremely low hourly wages of numerous workers. The logarithmic transformation can be expressed in the following formula:

$\log _{\mathrm{b}}(x)=y$ if $\mathrm{b}^{y}=x$

$\log _{\mathrm{b}}(x+y)=\log _{\mathrm{b}}(x) \log _{\mathrm{b}}(y)$

$\log _{10}(\mathrm{x}) \approx 2.30 \log _{\mathrm{e}}(\mathrm{x})$

$\mathrm{e} \approx 2.718$

First, a common use of logarithm in statistics is as a data transformation procedure to make samples more normally distributed and variances less unequal. The distribution looks much more symmetric after the log transformation (with less skew and fewer outliers). 
Sakamoto et al. (2000) note that the distribution of log-wage is concave; it does not need to be normally distributed but has to be symmetric. ${ }^{14}$

Second, the log transformation helps us treat multiplicative effects, which are difficult to handle using classical statistical methods, as additive effects. For example, after the antilog to interpret coefficients, we understand how many times one group earns more (or less) than another group (e.g., male versus female), instead of only getting information about how many dollars one group earns more (or less) than another group.

For ease of interpretation, we antilog to go back to the original scale. The dependent variable does not change throughout the process; it is always "the natural logarithm of hourly wage." However, it does not make sense or it is difficult to interpret the natural logarithm without the antilog because the natural logarithm of hourly wage does not exist in the real world. That is why the data themselves suggest the need for a logarithm transformation. Only after the antilog, are we able to get the ratio of median hourly wage of one group to another group, that is, how many times one group's median hourly wage is more (or less) than that of another group, instead of only getting the information about how many dollars one group earns more (or less) than another group. ${ }^{15}$

\section{Diagnostics}

The skewness and distribution of the hourly wages before and after the logarithmic transformation are compared. The original data have the median hourly wage of $\$ 9.62$, and $\$ 11.36$ standard deviation. The skewness is 8.9 , variance is 128.98 , and kurtosis is 141.81 . The distribution is therefore highly skewed to the right, with a number of low hourly wages. After the logarithmic transformation, on the other hand, the data are more normally

\footnotetext{
${ }^{14}$ Refer to Display 3.2 in Ramsey and Schafer (1997:55).

${ }^{15}$ See Display 3.7 in Ramsey and Schafer (1997:66); they explain how the log transformation works.
} 
distributed with fewer outliers. The median hourly wage is 2.26 , and the standard deviation is 0.62 . The skewness is 0.12 , variance is 0.38 , and kurtosis is 2.44 . Accordingly, these improvements in distribution encourage me to use the natural logarithm of hourly wage as the dependent variable.

Collinearity between the independent variables was also tested. The correlation matrices for the whole sample and the immigrant-only sample show that collinearity is not a major problem, as all correlations are 0.4 or lower. While all the correlations are statistically significant $(\mathrm{p}<0.0001)$, large sample sizes can contribute to small correlations being highly significant (Pett et al., 2003).

Finally, heteroscedasticity tests are conducted using White's test. One of the assumptions for OLS multiple linear regression is that error terms have equal variances. If there is heteroscedasticity, although an OLS regression is still unbiased, it will not be the most efficient. Heteroscedasticity also inflates the standard errors, thus obscuring potentially significant relationships. For each of the eight multiple linear regression models (Model 1 4), I tested the null hypothesis of White's test.

$$
\mathrm{H}_{0}: \sigma_{i}{ }^{2}=\sigma^{2} \text { for all } i
$$

Diagnostics show that there is no serious heteroscedasticity issue across all of the models in the analysis, as the Chi-Square tests are statistically significant $(\mathrm{p}<.05)$. Hence, these are good models with moderate adjusted R-squares (see Tables 3-8, 10 and 11). Reflecting the large sample size, almost all $p$-values of the coefficients are very small $(\mathrm{p}<0.0001)$. 


\section{CHAPTER IV}

\section{FINDINGS}

This chapter presents findings related to the assessment of the cost of being a Mexican immigrant and being a Mexican non-citizen in California and Texas. The chapter consists of various sections. First, I provide an overview of the descriptive statistics associated with the variables used in the analysis. Second, I describe the distribution of the Mexican-origin population along the lines of nativity and naturalization status across the two states. Third, I discuss the relationship between immigrants' duration of stay in the United States and hourly wages. Fourth, I provide a discussion of the multivariate analyses related to the cost of being a Mexican immigrant and being a Mexican non-citizen in California and Texas. Finally, I present a series of supplementary analyses.

\section{Descriptive Statistics}

Table 2 illustrates the descriptive statistics based on variables used in the analysis. U.S.-born Mexican Americans (G2) had an average hourly wage that was $\$ 3.61$ higher than that of their immigrant counterparts (G3) in California compared to an advantage of only $\$ 1.98$ in Texas. Similarly, among foreign-born Mexican workers, U.S. naturalized citizens (G4) in California had a greater average hourly wage advantage (\$3.65) over their noncitizen counterparts (G5) in California than was the case in Texas (\$2.44). As such, the descriptive results suggest that there is a greater cost in being an immigrant and in being a non-citizen immigrant in California than in Texas, with the cost being 1.8 and 1.5 times higher, respectively, in California than in Texas.

Nonetheless, at least part of the hourly wage variations between the native- and foreign-born and between citizen and non-citizen immigrants reflects differences in social 
Table 2. Descriptive Statistics Based on Variables Used in the Analysis

\section{California}

Variables

Mean Hourly Wage

Mean Age

Male

Engabil

Metrores

Education

Some High School

HS Graduate

Some College

College Graduate

Reference Group

\section{Occupation}

Mgrprorl

Service

Salesoff

Cnstexmn

Prtrmtmv

Reference Group

Selfemp

$$
\text { G1 } 12.47
$$

35
$63.35 \%$

$71.50 \%$

$87.89 \%$

G2

14.64

34
$54.67 \%$

$97.84 \%$

$87.70 \%$

$20.87 \%$

$22.51 \%$

$23.13 \%$

$7.20 \%$

$26.29 \%$

$16.12 \%$

$29.97 \%$

$38.35 \%$

$11.98 \%$

$3.59 \%$

$14.43 \%$

$18.66 \%$

$23.66 \%$

$14.37 \%$

$33.30 \%$

$21.81 \%$

$13.00 \%$

$25.97 \%$

$6.13 \%$

$10.62 \%$

$16.61 \%$

$1.44 \%$

$1.96 \%$

$1.70 \%$
G4

36

$69.10 \%$

$54.08 \%$

$88.02 \%$

$24.01 \%$

$17.58 \%$

$13.06 \%$

$4.04 \%$

$41.31 \%$

$8.35 \%$

$21.49 \%$

$14.23 \%$

$14.57 \%$

$32.14 \%$

$9.21 \%$

$2.13 \%$
13.66

40
$60.93 \%$

$76.28 \%$

$88.44 \%$

$21.23 \%$

$20.15 \%$

$21.30 \%$

$7.14 \%$

$30.18 \%$

$14.63 \%$

$18.07 \%$

$19.23 \%$

$12.69 \%$

$30.55 \%$

$4.83 \%$

$2.51 \%$

G5
10.01
34
$72.28 \%$
$45.42 \%$
$87.86 \%$

$25.10 \%$

$16.58 \%$

$9.85 \%$

$2.83 \%$

$45.64 \%$

$5.90 \%$

$22.82 \%$

$12.29 \%$

$15.30 \%$

$32.76 \%$

$10.92 \%$

$1.98 \%$

\section{Texas}

G1

11.31

35.7

$62.42 \%$

$77.21 \%$

$65.35 \%$

$\mathrm{G} 2$
12.17
36

$5.18 \%$

$96.91 \%$

$59.57 \%$

G3

10.19
36

$71.79 \%$

$51.72 \%$

$72.84 \%$

G4

11.93

40

$64.80 \%$

$72.66 \%$

$67.33 \%$

G5

$74.59 \%$

$43.35 \%$

$75.04 \%$

$20.80 \%$

$25.35 \%$

$18.06 \%$

$24.34 \%$

$20.98 \%$

$19.97 \%$

$25.69 \%$

$21.88 \%$

$31.93 \%$

$16.84 \%$

$10.78 \%$

$17.21 \%$

$15.58 \%$

$9.03 \%$

$12.50 \%$

$4.55 \%$

$7.34 \%$

$8.20 \%$

$22.94 \%$

$7.05 \%$

$43.50 \%$

$34.51 \%$

$47.10 \%$

$17.02 \%$

$18.40 \%$

23.93\%

$8.10 \%$

$13.65 \%$

$5.88 \%$

$21.82 \%$

$19.29 \%$

$22.83 \%$

$18.68 \%$

$29.10 \%$

$12.02 \%$

$16.29 \%$

$10.31 \%$

$22.17 \%$

$26.75 \%$

$19.88 \%$

$29.49 \%$

$2.08 \%$

$1.03 \%$

$3.44 \%$

$2.93 \%$

$27.84 \%$

$2.23 \%$

$1.90 \%$

$2.66 \%$

$3.52 \%$

$2.31 \%$

G1: All Mexican-Origin Workers

G2: All Native-Born

G3: All Foreign-Born

G4: Foreign-Born U.S. Naturalized Citizens

G5: Foreign-Born without U.S. Citizenship

Source: 2000 5\% PUMS. 
and economic attributes that are associated with wages. For example, while the majority of native-born Mexican Americans speak English, only slightly more than half of the foreignborn speak English, although naturalized citizens (70\%) are more likely to speak English compared to non-citizens (approximately 45\%). In addition, the native-born have higher education than their foreign-born counterparts in both states. For instance, the native-born are 2.3 times more likely to be high school graduates compared to their foreign-born counterparts of which only about one-third have a high school diploma. However, among the foreignborn, naturalized citizens are approximately 1.7 times more likely to have completed high school compared to their compatriots who have not become naturalized citizens.

There are also significant differences along nativity lines with respect to the types of jobs that Mexican-origin workers perform. In particular, more than half of the native-born work in higher status occupations (sales and office; and managerial and professional related occupations). In contrast, a significant majority of the foreign-born (76\% in Texas and 68\% in California) work in three blue-collar occupations (production, transportation, and material moving; construction, extraction, and maintenance; and service occupations). There are some differences, however, among the foreign-born population with naturalized citizens being less likely to be concentrated in these blue-collar occupations compared to those who are not naturalized citizens.

Overall, there are some differences among the Mexican-origin population across the two states. For example, those in California, regardless of nativity/citizenship status, are slightly more likely speak English and to be high school graduates compared to those in Texas. Moreover, the foreign-born are more likely to be employed in construction, extraction, and maintenance occupations compared to their counterparts in California. 


\section{Cost of Being a Mexican Immigrant and Being a Mexican Non-Citizen in California and Texas}

The analysis reported above provides preliminary evidence for the hypothesesnamely that immigrants and those that are not naturalized citizens experience wage penalties for their status and that this cost is greater in California than in Texas. However, because of the compositional differences pointed out above, it is necessary to examine the hypotheses using multivariate analysis. Table 3 presents the first set of two multiple linear regression models comparing the difference in predicted log of hourly wages between the foreign-born and native-born Mexican-origin workers in California and Texas. All variables included in the model, except for self-employment (selfemp) in the Texas model, are statistically significant.

As hypothesized, being a Mexican immigrant (imm) is disadvantageous with respect to earnings in both states, and the cost of being a foreign-born worker is higher in California than in Texas. Specifically, in the California model, it is estimated that the median hourly wage of a given foreign-born worker is 0.9399 times as high as that of a given native-born worker. Thus, the median hourly wage of foreign-born workers is estimated to be 6 percent lower than that of their native-born peers. In the Texas model, on the other hand, the median hourly wage of a given foreign-born worker is estimated to be only 2 percent lower than that of a given native-born worker. The relative nativity gap is therefore three times larger in California. Although the issue of uncontrolled differences in wages and costs of living across the states remains, the between-group difference in the costs of being an immigrant is statistically significant:

$$
\begin{aligned}
t & =\beta_{1}-\beta_{2} / \sqrt{ } \sigma_{1}{ }^{2}+\sigma_{2}^{2} \\
& =0.9826-0.9399 / \sqrt{ } 0.0047^{2}+0.0035^{2}=7.30>1.96(\mathrm{p}<.05, \text { two-tailed })
\end{aligned}
$$


Table 3. The Cost of Being a Mexican Immigrant in California and Texas: Multiple Linear Regression Results for the Dependent Variable "the Natural Logarithm of the Hourly Wage"

Model 1B: TX Whole

Model 1A: CA Whole Sample Sample

\begin{tabular}{|c|c|c|c|c|c|c|}
\hline \multirow[b]{2}{*}{ Variable } & \multicolumn{3}{|c|}{$\mathrm{N}=140,381$} & \multicolumn{3}{|c|}{$\mathrm{N}=80,985$} \\
\hline & Exp (Coef.) & Std. Err. & $\mathbf{t}$ & Exp (Coef.) & $\begin{array}{l}\text { Std. } \\
\text { Err. }\end{array}$ & $\mathbf{t}$ \\
\hline Age & $1.0151 * * * *$ & 0.0001 & 109.99 & $1.0114 * * * *$ & 0.0002 & 66.79 \\
\hline Male & $1.2144 * * * *$ & 0.0032 & 60.88 & $1.2409 * * * *$ & 0.0043 & 50.64 \\
\hline Engabil & $1.1712 * * * *$ & 0.0038 & 41.21 & $1.1712 * * * *$ & 0.0054 & 20.36 \\
\hline Metrores & $1.04656 * * * *$ & 0.0045 & 10.15 & $1.0970 * * * *$ & 0.0039 & 23.6 \\
\hline $\mathrm{Imm}$ & $0.9399 * * * *$ & 0.0035 & -17.62 & $0.9826^{* * *}$ & 0.0047 & -3.78 \\
\hline \multicolumn{7}{|l|}{ Education } \\
\hline Somehs & $1.0497 * * * *$ & 0.0044 & 10.97 & $1.0375 * * * *$ & 0.0059 & 6.26 \\
\hline Hsgrad & $1.739 * * * *$ & 0.0047 & 34.38 & $1.1617 * * * *$ & 0.0061 & 24.79 \\
\hline Somecoll & $1.3370 * * * *$ & 0.005 & 58.67 & $1.3224 * * * *$ & 0.0066 & 42.59 \\
\hline Collgrad & $1.6839 * * * *$ & 0.007 & 74.21 & $1.7924 * * * *$ & 0.0086 & 66.72 \\
\hline \multicolumn{7}{|l|}{ Occupation } \\
\hline Mgrpror1 & $1.5731 * * * *$ & 0.0077 & 58.79 & $1.5786 * * * *$ & 0.0138 & 32.98 \\
\hline Service & $1.1271 * * * *$ & 0.0068 & 17.54 & $1.1094 * * * *$ & 0.0132 & 7.88 \\
\hline Salesoff & $1.3344 * * * *$ & 0.0071 & 40.4 & $1.3340 * * * *$ & 0.0135 & 21.43 \\
\hline Cnstexmn & $1.4670 * * * *$ & 0.0072 & 53.16 & $1.3936 * * * *$ & 0.0131 & 25.36 \\
\hline Prtrmtmv & $1.2705 * * * *$ & 0.0066 & 36.39 & $1.3728 * * * *$ & 0.013 & 24.44 \\
\hline Selfemp & $0.9550 * * * *$ & 0.0102 & -4.5 & 1.011 & 0.0124 & 0.89 \\
\hline Constant & $3.127769 * * * *$ & 0.0092 & 123.54 & $3.0009 * * * *$ & 0.0156 & 70.39 \\
\hline
\end{tabular}

Source: 2000 5\% PUMS.

$* * * *$ Significant at the .0001 level;

*** Significant at the .0005 level.

CA Model Adj R-Sq $=.2720 ;$ TX Model Adj R-Sq $=.2503$ 
As can be seen, being an immigrant is a major source of the internal wage gap, and social and economic contexts matter with respect to the labor market outcomes of Mexican immigrants. I argue that the more hostile environment that immigrants face in California than in Texas - represented in a series of California propositions and related anti-immigrant sentiments - contribute to the greater wage penalty that immigrants experience in California.

Table 4 presents the second set of multiple linear regression models comparing the costs of being a Mexican non-citizen between the two states. As hypothesized, being a noncitizen significantly drops foreign-born workers' predicted hourly wages across the states, and this cost is again higher in California than in Texas. In California, the median hourly wage of a given Mexican non-citizen worker is estimated to be 14 percent lower than that of a given naturalized-citizen worker. In Texas, on the other hand, a given non-citizen worker's median hourly wage is estimated to be 10 percent lower than that of a given naturalizedcitizen worker. The relative citizenship gap is therefore 1.4 times larger in California. The cross-state difference in the cost associated with non-naturalized status is statistically significant, although cross-state differences in wages and costs of living are not controlled:

$$
\begin{aligned}
t & =\beta_{1}-\beta_{2} / \sqrt{ } \sigma_{1}{ }^{2}+\sigma_{2}^{2} \\
& =0.8998-0.8581 / \sqrt{ } 0.0044^{2}+0.0044^{2}=6.73>1.96(\mathrm{p}<.05, \text { two-tailed })
\end{aligned}
$$

The "dual costs" of being a Mexican immigrant without U.S. citizenship are indicated in the literature. In the post-IRCA period, legal status — rather than human capital attributes — has emerged as the primary determinant of immigrants' wage rates (Davila et al., 1998; Donato and Massey, 1993; Donato et al., 1992a; Massey, 1987b; Philip and Massey, 1999). To supplement the argument of wage gaps based on nativity difference and the possession of U.S. citizenship, four additional models with a California dummy variable 
Table 4. The Cost of Being a Mexican Non-Citizen in California and Texas: Multiple Linear Regression Results for the Dependent Variable “the Natural Logarithm of the Hourly Wage”

\begin{tabular}{|c|c|c|c|c|c|c|}
\hline \multirow[b]{2}{*}{ Variable } & \multicolumn{3}{|c|}{$\begin{array}{l}\text { Model 2A: CA Immigrant-Only Sample } \\
\qquad(\mathrm{N}=84,447)\end{array}$} & \multicolumn{3}{|c|}{$\begin{array}{l}\text { Model 2B: TX Immigrant-Only } \\
\text { Sample } \\
\qquad(\mathrm{N}=35,293)\end{array}$} \\
\hline & $\operatorname{Exp}$ (Coef.) & Std. Err. & $\mathbf{t}$ & $\operatorname{Exp}$ (Coef.) & Std. Err. & $\mathbf{t}$ \\
\hline Age & $1.0101 * * * *$ & 0.0002 & 53.96 & $1.0067 * * * *$ & 0.0003 & 24.27 \\
\hline Male & $1.2405 * * * *$ & 0.0041 & 52.68 & $1.2781 * * * *$ & 0.0068 & 35.97 \\
\hline Engabil & $1.1548 * * * *$ & 0.004 & 35.94 & $1.1176 * * * *$ & 0.006 & 18.45 \\
\hline Metrores & $1.0197 * *$ & 0.0058 & 3.37 & $1.0758 * * * *$ & 0.0064 & 11.49 \\
\hline Nocit & $0.8581 * * * *$ & 0.0044 & -35.11 & $0.8998 * * * *$ & 0.0044 & -15.92 \\
\hline \multicolumn{7}{|l|}{ Education } \\
\hline Somehs & $1.0377 * * * *$ & 0.0048 & 7.74 & $1.0217^{*}$ & 0.0072 & 2.96 \\
\hline Hsgrad & $1.1305 * * * *$ & 0.0054 & 22.61 & $1.1027 * * * *$ & 0.0084 & 11.67 \\
\hline Somecoll & $1.2592 * * * *$ & 0.0063 & 36.81 & $1.1745 * * * *$ & 0.0102 & 15.73 \\
\hline Collgrad & $1.4571 * * * *$ & 0.0101 & 37.34 & $1.4741 * * * *$ & 0.0151 & 25.7 \\
\hline \multicolumn{7}{|l|}{ Occupation } \\
\hline Mgrprorl & $1.5657 * * * *$ & 0.0095 & 47.00 & $1.6501 * * * *$ & 0.019 & 26.38 \\
\hline Service & $1.1152 * * * *$ & 0.0074 & 14.72 & $1.1147 * * * *$ & 0.0164 & 6.62 \\
\hline Salesoff & $1.3225 * * * *$ & 0.0083 & 33.56 & $1.3477 * * * *$ & 0.0177 & 16.84 \\
\hline Cnstexmn & $1.4513 * * * *$ & 0.0079 & 46.92 & $1.3928 * * * *$ & 0.0161 & 20.57 \\
\hline Prtrmtmv & $1.2611 * * * *$ & 0.0071 & 32.77 & $1.3909 * * * *$ & 0.016 & 20.67 \\
\hline Selfemp & $0.9582 * *$ & 0.0124 & -3.45 & $1.0656^{* * *}$ & 0.0172 & 3.69 \\
\hline Constant & $4.0905 * * * *$ & 0.0116 & 121.17 & $3.8044 * * * *$ & 0.0213 & 62.85 \\
\hline
\end{tabular}

Source: $20005 \%$ PUMS.

$* * * *$ Significant at the .0001 level; ***Significant at the .0005 level;

**Significant at the .001 level; *Significant at the .005 level;

CA Model Adj R-Sq = .2243; TX Model Adj R-Sq=0.1848. 
(California resident $=$ "1"; Texas resident $=$ "0") are estimated for four subgroups (nativeborn, foreign-born, foreign-born with U.S. citizenship, and foreign-born without U.S. citizenship) (Table 5, 6, 7, and 8). Largely due to the higher cost of living in California, all four groups have a "California wage advantage" (see Figure 2). However, the fact that the California wage advantage is 1.7 times larger in the case of the native-born than that of the foreign-born supports the argument regarding the more disadvantageous position of immigrants in California. The same is true with respect to naturalized citizenship, where the California wage advantage is twice greater among the naturalized citizens compared to those lacking this status. These four additional models provide further support to the findings from the initial analysis that being an immigrant and non-citizen reduce Mexican-origin workers' wages, and that these penalties are greater in California than in Texas.

Nevertheless, the analysis is based on an assumption that California and Texas have equal living expenses and state minimum wages. Considering that the analysis does not control differences in cost of living and state minimum wages ( $\$ 6.75$ in California and $\$ 5.15$ in Texas), the analysis may appear to violate the assumption. However, although I acknowledge the problem, I do not dismiss these latest results due to a long controversy among labor market researchers regarding these two components (living expenses and state minimum wages). First, researchers have not agreed on the definitions of living expenses (e.g., auto, public transportation, air conditioner, and heater) as most living expenses are fluid. Second, cross-state wage differences are naturally difficult to take into account. For instance, those in California are more likely to work in service industries while those in Texas are more likely to work in construction. Furthermore, considering the fact that many of Mexican immigrants are involved in food service industries and agriculture, state minimum 
Table 5. The Hourly Wage Difference of Native-Born Mexican American Workers in California and Texas: Multiple Linear Regression Results for the Dependent Variable “the Natural Logarithm of the Hourly Wage”

\begin{tabular}{lccc}
\hline Variable & Exp (Coef.) & Std. Err. & t \\
\hline Age & $1.0166 * * * *$ & 0.0001 & 109.99 \\
Male & $1.2018 * * * *$ & 0.0032 & 60.88 \\
Engabil & $1.0638 * * * *$ & 0.0038 & 41.21 \\
Metrores & $1.1031 * * * *$ & 0.0045 & 10.15 \\
CA & $1.1715 * * * *$ & 0.0035 & 17.62 \\
Education & & & \\
Somehs & $1.1177 * * * *$ & 0.0044 & 10.97 \\
Hsgrad & $1.2928 * * * *$ & 0.0047 & 34.38 \\
Somecoll & $1.4943 * * * *$ & 0.005 & 58.67 \\
Collgrad & $2.0160 * * * *$ & 0.007 & 74.21 \\
Occupation & & & \\
Mgrpror1 & $1.6060 * * * *$ & 0.0077 & 58.79 \\
Service & $1.1906 * * * *$ & 0.0068 & 17.54 \\
Salesoff & $1.3917 * * * *$ & 0.0071 & 40.4 \\
Cnstexmn & $1.5051 * * * *$ & 0.0072 & 53.16 \\
Prtrmtmv & $1.3849 * * * *$ & 0.0066 & 36.39 \\
Selfemp & $0.9577 * * *$ & 0.0102 & -4.5 \\
Constant & & & 123.54 \\
\hline
\end{tabular}

Source: 2000 5\% PUMS.

$* * * *$ Significant at the .0001 level.

$* * *$ Significant at the .001 level.

Adj R-Sq $=.2923$.

$\mathrm{N}=101,626$. 
Table 6. The Hourly Wage Difference of Foreign-Born Mexicans in California and Texas: Multiple Linear Regression Results for the Dependent Variable "the Natural Logarithm of the Hourly Wage”

\begin{tabular}{lccc}
\hline Variable & Exp (Coef.) & Std. Err. & t \\
\hline Age & $1.0107 * * * *$ & 0.0001 & 70.98 \\
Male & $1.2411 * * * *$ & 0.0035 & 61.29 \\
Engabil & $1.1754 * * * *$ & 0.0033 & 49.19 \\
Metrores & $1.0400 * * * *$ & 0.0043 & 9.11 \\
CA & $1.1022 * * * *$ & 0.0034 & 28.32 \\
Education & & & \\
Somehs & $1.0412 * * * *$ & 0.004 & 10.06 \\
Hsgrad & $1.1376 * * * *$ & 0.0046 & 28.17 \\
Somecoll & $1.2664 * * * *$ & 0.0053 & 44.19 \\
Collgrad & $1.4925 * * * *$ & 0.0084 & 47.5 \\
Occupation & & & \\
Mgrprorl & $1.6099 * * * *$ & 0.0084 & 56.5 \\
Service & $1.1120 * * * *$ & 0.0067 & 15.86 \\
Salesoff & $1.3392 * * * *$ & 0.0075 & 39.13 \\
Cnstexmn & $1.4305 * * * *$ & 0.0069 & 51.67 \\
Prtrmtmv & $1.2981 * * * *$ & 0.0064 & 40.72 \\
Selfemp & & 0.0101 & -1.01 \\
Constant & & & \\
\hline
\end{tabular}

Source: 2000 5\% PUMS.

$* * * *$ Significant at the .0001 level.

Adj R-Sq $=.2028$.

$\mathrm{N}=119,740$. 
Table 7. The Hourly Wage Difference of Foreign-Born with Citizenship in California and Texas: Multiple Linear Regression Results for the Dependent Variable "the Natural Logarithm of the Hourly Wage"

\begin{tabular}{lccc}
\hline Variable & Exp (Coef.) & Std. Err. & t \\
\hline Age & $1.0079 * * * *$ & 0.0003 & 26.2 \\
Male & $1.3150 * * * *$ & 0.0064 & 42.61 \\
Engabil & $1.1499 * * * *$ & 0.0072 & 19.28 \\
Metrores & $1.0779 * * * *$ & 0.0079 & 9.46 \\
CA & $1.1621 * * * *$ & 0.0065 & 23.05 \\
Education & & & \\
Somehs & $1.0503 * * * *$ & 0.0084 & 5.86 \\
Hsgrad & $1.1515 * * * *$ & 0.0088 & 16.05 \\
Somecoll & $1.3140 * * * *$ & 0.0093 & 29.51 \\
Collgrad & $1.6465 * * * *$ & 0.0135 & 36.99 \\
Occupation & & & \\
Mgrprorl & $1.6109 * * * *$ & 0.0172 & 27.8 \\
Service & $1.1427 * * * *$ & 0.0158 & 8.42 \\
Salesoff & $1.3799 * * * *$ & 0.0164 & 19.63 \\
Cnstexmn & $1.5075 * * * *$ & 0.0162 & 25.29 \\
Prtrmtmv & $1.3685 * * * *$ & 0.0152 & 20.67 \\
Selfemp & & 0.0174 & -1.03 \\
Constant & & & \\
\hline
\end{tabular}

Source: 2000 5\% PUMS.

$* * * *$ Significant at the .0001 level.

Adj R-Sq $=.2278$.

$\mathrm{N}=33,767$. 
Table 8. The Hourly Wage Difference of Foreign-Born without Citizenship in California and Texas: Multiple Linear Regression Results for the Dependent Variable "the Natural Logarithm of the Hourly Wage"

\begin{tabular}{|c|c|c|c|c|}
\hline Variable & $\operatorname{Exp}$ (Coef.) & & Std. Err. & t \\
\hline Age & $1.0095 * * * *$ & & 0.0002 & 52.54 \\
\hline Male & $1.2234 * * * *$ & & 0.0042 & 48.16 \\
\hline Engabil & $1.1419 * * * *$ & & 0.0038 & 35.38 \\
\hline Metrores & $1.0284 * * * *$ & & 0.0051 & 5.51 \\
\hline $\mathrm{CA}$ & $1.0793 * * * *$ & & 0.004 & 19.07 \\
\hline \multicolumn{5}{|l|}{ Education } \\
\hline Somehs & $1.0311 * * * *$ & & 0.0045 & 6.76 \\
\hline Hsgrad & $1.1177 * * * *$ & & 0.0054 & 20.82 \\
\hline Somecoll & $1.2004 * * * *$ & & 0.0067 & 27.24 \\
\hline Collgrad & $1.3493 * * * *$ & & 0.011 & 27.2 \\
\hline \multicolumn{5}{|l|}{ Occupation } \\
\hline Mgrprorl & $1.5898 * * * *$ & & 0.0102 & 45.67 \\
\hline Service & $1.1076 * * * *$ & & 0.0073 & 13.94 \\
\hline Salesoff & $1.3139 * * * *$ & & 0.0085 & 32.16 \\
\hline Cnstexmn & $1.4056 * * * *$ & & 0.0076 & 44.7 \\
\hline Prtrmtmv & $1.2726 * * * *$ & & 0.007 & 34.32 \\
\hline Selfemp & & 0.9972 & 0.0124 & -0.23 \\
\hline Constant & $3.3846^{* * * *}$ & & 0.0105 & 116.51 \\
\hline
\end{tabular}

Source: 2000 5\% PUMS.

$* * * *$ Significant at the .0001 level.

Adj R-Sq $=.1537$.

$\mathrm{N}=85,972$. 
Figure 2. California Relative Wage Advantage Over Texas from OLS Regressions by Nativity and the U.S. Citizenship Status of the Foreign Born

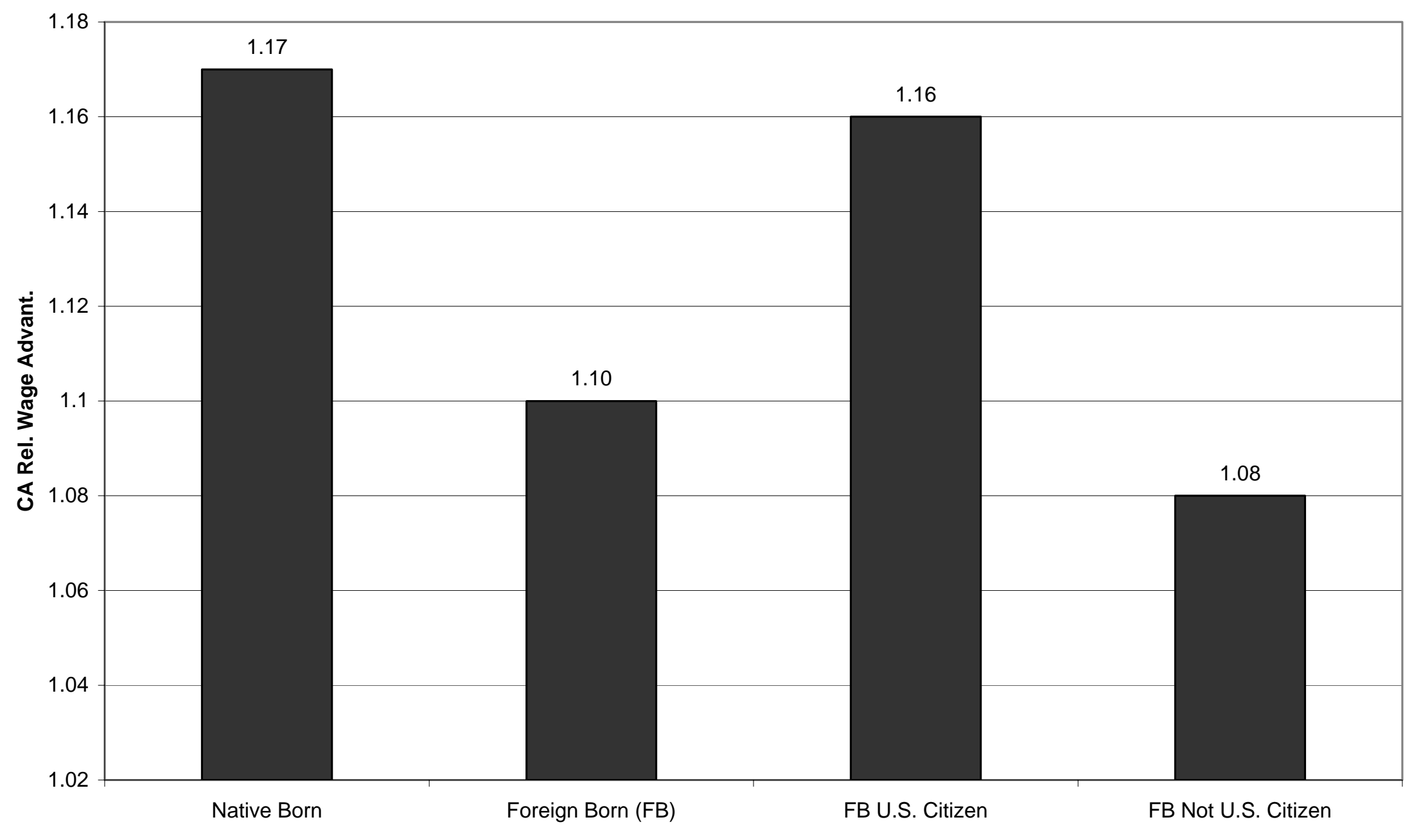


wages do not apply to all of the Mexican-origin workers. Third, there are a number of regional variations within the states as both California and Texas are relatively large states. Fourth, my interest is on comparing the California-Texas wage gaps between the native- and foreign-born and the naturalized citizens and non-naturalized citizens with the understanding that cost of living and minimum wage differences between the states are fairly consistent across models (subgroups). Hence, this last set of findings does have validity.

As increases in the supply of immigrant labor force have a strong impact on the earnings of immigrants themselves (especially those without U.S. citizenship) (Borjas, 1987a, 1987b, 1994, 1995; Topel, 1994), frequency distributions of Mexican immigrants are also taken into account (see Table 9). First, the foreign-born represent a much larger share of the Mexican-origin population in California than in Texas. Three-fifths (60.2\%) of the Mexican-origin population in California is foreign-born, whereas nearly three-fifths (56.4\%) in Texas are native-born. Second, while there are 1.22 native-born Mexican Americans in California to every one native-born Mexican American in Texas, the respective ratio is 2.39 with respect to the foreign-born population. Third, the size of the California immigrant population is larger than that of the Texas immigrant population regardless of period of U.S. entry and naturalization status. However, it is clear that among the Mexican immigrant population, those that first immigrated to the United States since 1990 (the most recent immigrants) account for a larger share of the Texas immigrant population (38.7\%) compared to the California immigrant population (29.9\%). This perhaps signifies a change in the destination of Mexican immigrants away from California and toward Texas.

The higher costs associated with foreign-born status and the lack of naturalization status in California appear to reflect the harsher labor market conditions in which increases in 
Table 9. Distribution of the Mexican-Origin Population Used in the Study Sample by Nativity and Period of Entry and Naturalization Status among the Foreign-Born by State

\begin{tabular}{|c|c|c|c|}
\hline Nativity Status: & California & Texas & $\begin{array}{l}\text { California-Texas } \\
\text { Population Ratio }\end{array}$ \\
\hline U.S.-Born & $39.80 \%$ & $56.40 \%$ & 1.22 \\
\hline Total Mexican-Origin Population & 140,598 & 81,063 & 1.73 \\
\hline Came to the U.S. $<1970$ & $8.60 \%$ & $8.00 \%$ & 2.57 \\
\hline Came to the U.S. in $1970-1979$ & $24.90 \%$ & $21.40 \%$ & 2.78 \\
\hline Came to the U.S. in $1980-1989$ & $36.70 \%$ & $31.90 \%$ & 2.75 \\
\hline Came to the U.S. in $1990-2000$ & $29.90 \%$ & $38.70 \%$ & 1.85 \\
\hline Total Foreign-Born Population & 84,616 & 35,331 & 2.39 \\
\hline \multicolumn{4}{|c|}{ Foreign-Born Population Naturalization Status: } \\
\hline Not U.S. Naturalized Citizens & $72 \%$ & $71.5 \%$ & 2.41 \\
\hline Total Foreign-Born Population & 84,616 & 35,331 & 2.39 \\
\hline
\end{tabular}

Source: 2000 5\% PUMS. 
the supply of immigrants, especially those who arrived after 1990, may have contributed to a lowering of the average hourly wage of the Mexican immigrant population in California. On the other hand, the smaller costs based on the immigrant status and the lack of U.S. citizenship in Texas may be partly explained by the smaller immigrant population which suggests a less intensive wage competition among the foreign-born in Texas.

\section{Length of U.S. Residence and the Cost of Being a Mexican Immigrant and Non-Citizen}

The literature notes that immigrants' wages differ depending on their length of stay in the United States, because immigrants generally improve their wage returns to their human capital with time spent in this country. Furthermore, the literature suggests that the social and economic configurations of immigrants differ with respect to the period in which immigrants come to the United States. Thus, in addition to the costs associated with foreign-born status and the lack of naturalized status, the time when a Mexican worker came to the United States needs to be taken into account.

Table 10 examines variations in costs associated with foreign-born status by four periods of entry into the United States. The results show two important patterns. First, the most recent immigrants — those who arrived during the last decade (imm9000) — had the lowest wages relative to the native-born, all else equal, in both states. Second, the most recent immigrants in California had hourly wages that were 14 percent below their nativeborn counterparts, with the respective difference being only 6 percent in Texas. The 2.3 times higher relative gap of imm9000 in California than imm9000 in Texas (14\% to 6\%) is statistically significant, although cross-state wage differences are not controlled $(t=9.51>$ $1.96, \mathrm{p}<.05$, two-tailed). 
Table 10. The Cost of Being a Mexican Immigrant in California and Texas: Multiple Linear Regression Results for the Dependent Variable "the Natural Logarithm of the Hourly Wage”: With Length of U.S. Residence

\begin{tabular}{|c|c|c|c|c|c|c|}
\hline & \multicolumn{3}{|c|}{$\begin{array}{l}\text { Model 3A: CA Whole Sample } \\
\mathrm{N}=140,381\end{array}$} & \multicolumn{3}{|c|}{$\begin{array}{l}\text { Model 3B: TX Whole Sample } \\
\mathrm{N}=80,985\end{array}$} \\
\hline Variable & $\operatorname{Exp}$ (Coef.) & Std. Err. & t & $\operatorname{Exp}$ (Coef.) & Std. Err. & $\mathbf{t}$ \\
\hline Age & $1.0136 * * * *$ & 0.0002 & 88.84 & $1.0110 * * * *$ & 0.0002 & 60.13 \\
\hline Male & $1.2170 * * * *$ & 0.0032 & 61.67 & $1.2420 * * * *$ & 0.0043 & 50.89 \\
\hline Engabil & $1.1407 * * * *$ & 0.004 & 33.12 & $1.0998 * * * *$ & 0.0056 & 17.1 \\
\hline Metrores & $1.0486 * * * *$ & 0.0045 & 10.59 & $1.0985 * * * *$ & 0.0039 & 23.95 \\
\hline \multicolumn{7}{|c|}{ Length of U.S. Residence } \\
\hline Imm0069 & $0.9782 * *$ & 0.007 & -3.15 & $0.9493 * * * *$ & 0.0104 & -4.98 \\
\hline Imm7079 & $0.9835^{* * *}$ & 0.0047 & -3.54 & $1.0206^{* *}$ & 0.0069 & 2.95 \\
\hline Imm8089 & $0.9426 * * * *$ & 0.0043 & -13.81 & 1.0068 & 0.0061 & 1.1 \\
\hline Imm9000 & $0.8621 * * * *$ & 0.0049 & -30.1 & $0.9357 * * * *$ & 0.0064 & -10.33 \\
\hline \multicolumn{7}{|l|}{ Education } \\
\hline Somehs & $1.0535 * * * *$ & 0.0044 & 11.79 & $1.0417 * * * *$ & 0.0059 & 6.94 \\
\hline Hsgrad & $1.1779 * * * *$ & 0.0047 & 35.14 & $1.1656 * * * *$ & 0.0061 & 25.34 \\
\hline Somecoll & $1.3391 * * * *$ & 0.005 & 59.02 & $1.3265 * * * *$ & 0.0066 & 43.07 \\
\hline Collgrad & $1.6954 * * * *$ & 0.007 & 75.27 & $1.8045 * * * *$ & 0.0088 & 67.44 \\
\hline \multicolumn{7}{|l|}{ Occupation } \\
\hline Mgrpror1 & $1.5633 * * * *$ & 0.0077 & 58.08 & $1.5803 * * * *$ & 0.0138 & 33.1 \\
\hline Service & $1.1274 * * * *$ & 0.0068 & 17.61 & $1.1130 * * * *$ & 0.0132 & 8.12 \\
\hline Salesoff & $1.3245 * * * *$ & 0.0071 & 39.41 & $1.3347 * * * *$ & 0.0134 & 21.5 \\
\hline Cnstexmn & $1.4621 * * * *$ & 0.0072 & 52.8 & $1.3974 * * * *$ & 0.0131 & 25.59 \\
\hline Prtrmtmv & $1.2633 * * * *$ & 0.0066 & 35.59 & $1.3731 * * * *$ & 0.013 & 24.49 \\
\hline Selfemp & $0.9548 * * * *$ & 0.0102 & -4.53 & 1.009 & 0.0124 & 0.72 \\
\hline Constant & $3.3729 * * * *$ & 0.0098 & 123.94 & $3.0678 * * * *$ & 0.016 & 70.19 \\
\hline
\end{tabular}

\footnotetext{
Source: 2000 5\% PUMS.

**Significant at the .005 level; ***Significant at the .0005 level; ****Significant at the .0001 level.
}

CA Model Adj R-Sq = .2753; TX Model Adj R-Sq $=.2520$ 
Their highest cost of being an immigrant who arrived since 1990 can be partly accounted for by their shorter duration of stay in the U.S. and lower levels of human capital (e.g., English language proficiency and U.S. labor market experiences), although the multivariate analysis takes such compositional differences into account. Furthermore, the large cost among the most recent immigrants may be at least partly associated with the nation wide anti-immigrant sentiments leading initially to the passage of IRCA and to further animus against immigrants especially in California in the 1990s. It is also likely that the most recent arrivals are also less likely to be naturalized citizens, an increasingly debilitating factor in wage attainment in the post-IRCA period.

The patterns are relatively different for those who have been in the country longer. Mexican immigrants who arrived before 1990 display relatively lower costs for their immigrant status, suggesting that a combination of their human capital improvement with duration of stay in the United States and possibly higher rates of naturalization enabled them to reduce their wage penalties attached to their immigrant status.

In California, foreign-born Mexicans who arrived before 1970 (imm0069) and between 1970 and 1979 (imm7079) had hourly wages that were only 2 percent lower than those of their native-born counterparts. In Texas, on the other hand, imm0069 and imm7079 are associated with $5 \%$ percent lower and 2 percent higher wages, respectively. This finding appears to suggest shifts in the Mexican labor market core from Texas to California. The literature notes that compared to California, Mexican immigrant workers in Texas faced a severe internal wage competition before 1970. Starting from the bracero program between 1942 and 1964, immigrant workers had lower wages than the native-born, especially in agricultural industries (Jenkins, 1977; cited in Valdes, 1995; Sandos and Cross, 1983; 
Valdes, 1995). The cross-state differences in imm0069 $(t=2.37>1.96, \mathrm{p}<.05$, two-tailed $)$ and imm7079 $(t=4.42>1.96, \mathrm{p}<.05$, two-tailed $)$ are also statistically significant, although between-state wage differences are not controlled.

On the other hand, foreign-born Mexicans who arrived California between 1980 and 1989 (imm8089) had 6 percent lower wages than those of their native-born counterparts. It is likely that the higher cost of being an immigrant attached to this cohort than the costs attached to earlier arrivals (imm0069 and imm7079) reflects the inception of the harsher treatment toward Mexican immigrants in the state, which led to the implementation of antiimmigrant propositions during the last decade and accordingly immigrant status became a major determinant of internal wage differences among the Mexican-origin workers.

The last set of models (Table 11) assess whether the significance of length of stay in the United States holds for non-citizens as well. Needless to say, length of stay in the United States and citizenship status are positively correlated. While the initial analysis (Model 2A and 2B) does not control immigrants' duration of U.S. residence, Model 4A and 4B present the cost of being a non-citizen controlling immigrants' length of U.S. residence.

While the cost of being a non-citizen is associated with 14 percent lower hourly wages in California and 10 percent lower wages in Texas in Model 2A and 2B, the foreignborn without U.S. citizenship have 11 percent and 8 percent lower wages in California and Texas, respectively, compared to the naturalized citizens in Model 4A and 4B, holding immigrants' length of stay in the U.S. constant. The cross-state difference in the nocit variable is statistically significant, although between-state wage differences are not controlled $(t=4>1.96, \mathrm{p}<.05$, two-tailed). 
Table 11. The Cost of Being a Mexican Non-Citizen in California and Texas: Multiple Linear Regression Results for the Dependent Variable "the Natural Logarithm of the Hourly Wage": Length of U.S. Residence Controlled

\begin{tabular}{|c|c|c|c|c|c|c|}
\hline \multirow[b]{2}{*}{ Variable } & \multicolumn{3}{|c|}{$\begin{array}{l}\text { Model 4A: CA Immigrant-Only Sample } \\
\mathrm{N}=84,447\end{array}$} & \multicolumn{3}{|c|}{$\begin{array}{l}\text { Model 4B: TX Immigrant-Only Sample } \\
\mathrm{N}=35,293\end{array}$} \\
\hline & $\operatorname{Exp}$ (Coef.) & Std. Err. & t & Exp (Coef.) & Std. Err. & $\mathbf{t}$ \\
\hline Age & $1.0060^{* *}$ & 0.0002 & 26.77 & $1.0044 * *$ & 0.0003 & 13.62 \\
\hline Male & $1.2433 * *$ & 0.0041 & 53.58 & $1.2816^{* *}$ & 0.0068 & 36.49 \\
\hline Engabil & $1.1177 * *$ & 0.0041 & 27.19 & $1.0902 * *$ & 0.0062 & 13.93 \\
\hline Metrores & $1.0253 * *$ & 0.0058 & 4.26 & $1.0799 * *$ & 0.0063 & 12.12 \\
\hline \multicolumn{7}{|c|}{ Cost of Being a Non-Citizen } \\
\hline Nocit & $0.8884 * *$ & 0.0045 & -26.54 & $0.9220 * *$ & 0.0068 & -11.92 \\
\hline $\operatorname{Imm} 7079$ & $0.9565 * *$ & 0.0073 & -6.1 & 1.02 & 0.0118 & 1.68 \\
\hline Imm8089 & $0.8905^{* *}$ & 0.0077 & -15.06 & 0.9797 & 0.0121 & -1.71 \\
\hline $\operatorname{Imm} 9000$ & $0.7926^{* *}$ & 0.0087 & -26.6 & $0.8902 * *$ & 0.0132 & -8.79 \\
\hline \multicolumn{7}{|l|}{ Education } \\
\hline Somehs & $1.0369 * *$ & 0.0048 & 7.62 & $1.0253 *$ & 0.0072 & 3.46 \\
\hline Hsgrad & $1.1302 * *$ & 0.0054 & 22.67 & $1.1034 * *$ & 0.0084 & 11.78 \\
\hline Somecoll & $1.2517 * *$ & 0.0062 & 36 & $1.1764 * *$ & 0.0102 & 15.93 \\
\hline Collgrad & $1.4734 * *$ & 0.01 & 38.66 & $1.5067 * *$ & 0.0151 & 27.14 \\
\hline \multicolumn{7}{|l|}{ Occupation } \\
\hline Mgrprorl & $1.5411 * *$ & 0.0095 & 45.58 & $1.6432 * *$ & 0.0189 & 26.25 \\
\hline Service & $1.1197 * *$ & 0.0074 & 15.36 & $1.1211 * *$ & 0.0164 & 6.99 \\
\hline Salesoff & $1.3051 * *$ & 0.0083 & 32.16 & $1.3418 * *$ & 0.0177 & 16.65 \\
\hline Cnstexmn & $1.4452 * *$ & 0.0079 & 46.7 & $1.3940 * *$ & 0.0161 & 20.7 \\
\hline Prtrmtmv & $1.2538 * *$ & 0.007 & 32.15 & $1.3888 * * * *$ & 0.0159 & 20.66 \\
\hline Selfemp & $0.9582 *$ & 0.0123 & -3.47 & $1.0634 *$ & 0.0172 & 3.59 \\
\hline Constant & $5.2982 * *$ & 0.0156 & 106.82 & $4.2742 * *$ & 0.0264 & 55.1 \\
\hline
\end{tabular}

Source: 2000 5\% PUMS.

*Significant at the .0005 level; **Significant at the .0001 level.

CA Model Adj R-Sq = .2348; TX Model Adj R-Sq $=.1912$ 
The slight reduction in the cost associated with a non-citizen status in Model 4 is accounted for by the fact that length of U.S. residence can decrease the cost of being a noncitizen. The significance of duration of stay in the United States is supported by the fact that three controlled variables, imm7079, imm8089, and imm9000, are all statistically significant. This pattern reflects the fact that immigrants' longer duration of stay in the U.S. has a combined effect of higher naturalization rates and human capital improvement (e.g., English language proficiency and more U.S. labor market experiences). Table 11 shows that length of U.S. residence is important for non-citizens to reduce the wage penalty associated with their lack of U.S. citizenship status.

\section{Human Capital Attributes and Other Factors}

Model 1 and Model 2 strongly suggest that high levels of human capital have much to do with higher expected wages earned by Mexican-origin workers. Age is positively associated with hourly wages, as age is regarded as a substitute factor measuring working experience. English language proficiency is strongly and positively associated with hourly wages. English language ability is particularly important for immigrants, as it is correlated with levels of education.

Hourly wages are also consistently associated with educational attainment. However, among immigrants, the location where the education took place is important. Indeed, the effect of education on wages is highly associated with nativity status. Namely, wage returns to education are consistently smaller in the immigrant-only sample (Model 2A and 2B) than in the whole sample (Model 1A and Model 1B), suggesting that schooling has a smaller impact on the earnings of the foreign-born than on those of the native-born (Chiswick et al., 1997). This is particularly the case regarding the two college-related variables. 
There is a wide range of literature addressing the skill-based technological change in which the demand for low-skill workers has fallen relative to workers with high-level skills (McCall, 2000b). The globalization of the U.S. economy is accompanied by changes in the U.S. wage structure in which workers with less education face lower wages and earnings (Borjas, 1999). Thus, college completion and more advanced studies (e.g., professional schools) are likely to be increasingly crucial determinants of the socioeconomic attainment of Mexican-origin workers.

The non-human capital variables are also significantly related to hourly wages. For example, males consistently have higher wages than their female counterparts across the states. However, the gender wage gap is greater among the foreign-born. The literature points out gender-related structural barriers in the Mexican-origin population, due to the numerical predominance of males (Marcelli and Cornelius, 2001; Roberts et al., 1999; Wallace, 1986). In fact, Saenz (2004a) reports a gender gap in labor force participation rates among Mexicans; while 71.4 percent of foreign-born males were in the labor force in 2000, only 47.7 percent of females were part of the labor force.

In addition, metropolitan area residents attain higher wages than those living in nonmetropolitan areas both in the first and second sets of models. However, wage returns to metropolitan area residence are higher in Texas than in California. This finding appears to reflect the higher population concentration of Mexican-origin workers in metropolitan areas in California (Wallace, 1986). In fact, research suggests that traditional metropolitan areas in California (e.g., Los Angeles) have been facing labor market saturation (Durand et al., 2000; Krissman, 2000; Suro and Singer, 2002). 
Five occupational categories are also included in the analysis. Wage returns are highest for those who work for professional, management and related occupations (mgrprorl) both in the whole Mexican-origin sample and immigrant-only sample. The literature suggests possible bifurcated wages between a relatively small portion of Mexican-origin workers that have specialized skills (Alarcon, 1999; Castells, 1996; Clark, 1998; Keely, 1974; Kritz, 1987; Pellegrino, 2001; Roberts et al., 1999) ${ }^{16}$ and disproportionate number of workers in the lowskilled and low-wage labor force (Massey and Schnabel, 1983; Portes and Truelove, 1987; Roos and Hennessy, 1987; Saenz and Torres, 2003; Waldinger, 1989a, 1989b, 1996). ${ }^{17}$

Wage returns to sales and office occupations (salesoff) are higher than service occupations (service) across the models. It is likely that sales and office occupations require higher levels of human capital, such as English-language proficiency and education. Wage returns for construction, extraction, and maintenance occupations (cnstexmn) are higher in California, but wage returns for production, transportation, and material moving occupations (prtrmtmv) are higher in Texas. Furthermore, the median hourly wages in cnstexmn are estimated to be higher than service and salesoff variables. There is only slight statistical evidence for the advantage of self-employment. As Borjas (1986) and Spencer and Bean (1999) point out, Mexican self-employment tends to be associated with disadvantaged labor market outcomes. However, one possible explanation for this observation is that the selfemployed tend to work many hours which brings down their hourly wages. ${ }^{18}$

\footnotetext{
${ }^{16}$ Alarcon (1999) notes the arrival of a large number of highly educated permanent residents and temporary workers during the early 1990s. Alarcon examines the processes by which Indian and Mexican engineers and scientists find employment in the high-technology companies in Silicon Valley.

${ }^{17}$ Espenshade and Goodis (1985) report that as of 1980, Mexican immigrant workers made up nearly 50 percent of the low-skilled manufacturing labor force in the standard metropolitan statistical area (SMSA).

${ }^{18}$ I also tested interaction effects to see whether the linear associations between human capital and other control variables and the hourly wage differ based on the nativity status and naturalization status. The results are presented in appendix.
} 
This chapter presented findings related to the assessment of the cost of being a Mexican immigrant and being a Mexican non-citizen in California and Texas, and a series of supplementary analyses. The next chapter presents a summary of the major findings, theoretical contributions of this study to Latino/a demography, implications of the findings to the immigrant policies, shortcomings and future directions of this study. 


\section{CHAPTER V}

\section{CONCLUSIONS}

For the comprehensive examination of the heterogeneity of Mexican-origin workers, this study focused on internal hourly wage differences within this group. Instead of estimating the Mexican-Anglo wage differences, which is the major approach guided by the ethnic labor market perspectives, I examined the labor market experiences of Mexican immigrants and how social context matters. Specifically, I focused on the cost of being an immigrant (the hourly wage differences between the native- and foreign-born) and the cost of being an immigrant without U.S. citizenship (the wage differences between naturalized immigrants and non-naturalized immigrants). By comparing the two largest concentration states of Mexican-origin workers in the United States, California and Texas, I also examined the impact of the state-specific labor market characteristics on Mexican immigrant workers' wages.

The results consistently show that foreign-born status and the lack of U.S. citizenship are correlated with lower hourly wages across the states. Reflecting anti-immigrant policies and sentiments, Mexican immigrants in California bear a higher cost for being foreign-born than their counterparts in Texas. Furthermore, non-U.S. naturalized foreign-born Mexicans face dual disadvantages with respect to wages, especially for those living in California. Partly, larger population concentration of immigrants, especially non-citizens, could be a source of intensive within-group labor market competition among the foreign-born workers.

The cost of being an immigrant was further examined in terms of immigrants' length of U.S. residence. Results show that immigrants who arrived during the last decade faced significant declines in wages across the states. Furthermore, the greater cost attached to this 
cohort in California confirms the finding from the initial analysis that Mexican immigrants faced harsher social contexts in California in the post-IRCA period, in which foreign-born status became a stronger determinant of wages over human capital differences. U.S.naturalized citizenship status is another central factor associated with foreign-born workers' wages, controlling for the passage of time in the United States.

Findings also support the importance of other individual attributes on wages. Regarding the selected human capital resources, education and English-language proficiency are associated with higher wage returns. Especially, college completion appears to be a principal factor of within-group wage differences. Lack of education will continue to block Mexican immigrants with lower levels of education, especially non-U.S. citizens, from access to better-paying jobs. Moreover, the results show significant wage differences between professional and non-professional occupational categories.

Major theoretical and empirical contributions of this study to Latino/a demography are noted. First, the findings show that nativity status (native- and foreign-born) and U.S. naturalized citizenship status (foreign-born with citizenship and non-citizen foreign-born status) are two major determinants of within-group wage differences, which are often missing in the labor market analysis of Mexican-origin workers (Bean et al., 1988; Bradshaw and Frisbie, 1983; Saenz, 2004b; Semyonov, 1988). Further analysis of the different labor market experiences within this group is encouraged, as the Mexican-origin population includes a number of historically disadvantaged foreign-born as well as continuing inflows of new immigrants. Second, findings show the importance of taking into account the effect of broad social contexts on wages beyond different types of labor market categories. As past studies tend to rely on small-scale case studies limited to specific occupations and industries, 
further analysis on the impact of regional differences on labor market experiences of Mexican-origin workers are needed.

The results of this study raise several important immigrant policy implications. Unlike the anti-immigrant sentiments against Mexican workers in the background of IRCA and California propositions, the findings strongly suggest that Mexican immigrants, particularly non-citizens, faced harsher labor market conditions after the implementation of IRCA. As the results show the importance of education and English language proficiency on wages, social welfare policies (e.g., public education for Limited-English-Proficiency (ELP) Mexicans) have to be reconsidered to avoid further internal wage gap based on lower levels of education and language problem. There is a great possibility that a disproportionate number of foreign-born Mexicans, especially non-citizens, stand in a disadvantaged labor market position due to a lack of human capital resources.

Furthermore, the negative impact of IRCA on non-citizen Mexican workers' wages indicates that current discussion on the revival of temporary guest worker program and a legalization program possibly result in wage penalties against non-citizen workers. Future immigrant policies should be carefully reformed by taking into account whether future policies really bring benefits to immigrant workers who are already in this country.

Several shortcomings of this study are also noted. First, the analysis did not control for the differences in living expenses and state minimum wages between California and Texas. Second, as the major focuses of this study were immigrant status and naturalization status, other individual attributes such as human capital resources were treated as control variables and thus not widely discussed. As almost all variables included in the analysis have 
significant effects on wages, further analysis has to be conducted to closely estimate the effect of various attributes on wages.

The third limitation is attributed to the data set used to conduct the analysis. In separating the immigrant population into the U.S.-naturalized citizens and non-citizens, the latter contains a wide variety of persons including undocumented immigrants and international college students. As undocumented workers may exert a large impact on the wages of other individuals (Bean et al., 1988; Briggs, 1983), the inseparable undocumented portion in the immigrant population in the PUMS data is certainly an unavoidable problem in this study. Also, skilled immigrants may not be permanent residents or naturalized citizens, who may hold temporary visas (the H-1B). Although I am interested in assessing the labor market outcomes for immigrants working in professional occupations, few, if any data sources, allow us to determine whether they remain in the United States for employment or return to their countries (see Bayer, 1968).

The PUMS data are widely used in earnings studies as they provide a large, nationally representative sample of all sectors of the labor force. Nonetheless, considering that there is a certain portion of foreign-born Mexicans involved in the underground economy and informal sectors, the cost of being a non-citizen could be much greater than the findings of this study suggest.

Fourth, I attributed the higher costs associated with foreign-born status and noncitizenship status in California to the anti-immigrant hostilities due to a higher population concentration of immigrants in that state. However, other possible factors associated with higher costs in California, industrial changes taking place between California and Texas, have not been discussed in this study. For example, the literature notes that immigrants in 
California faced declining wages during the 1990s due to a broad restructuring of the economy in California (Durand et al., 2000), while Texas experienced an effective labor demand due to rural industrialization.

Finally, future directions of this study are noted. This study estimated the cost of being an immigrant and being a non-citizen in California and Texas, two major concentration states in the Southwest. Further analysis needs to be conducted for testing the generalization of these costs in much broader social and economic contexts, such as in different standard Census regions and the entire United States. Particularly, future research needs to examine the labor market experiences of Mexican-origin workers in new-destination areas, places primarily in the South and Midwest where Mexicans, especially immigrants, have settled over the last decade. 


\section{REFERENCES}

Aiken, L. S. and S. G. West

1991 Multiple Regression: Testing and Interpreting Interactions. Newbury Park, CA: Sage Publications.

Aguilera, M. B.

2004 "The Effect of Legalization on the Labor Markets of Latin American Immigrants: A Gendered Comparison," Sociological Focus, 37: 349-369.

Alarcon, R.

2000 "Skilled Immigrants and Cerebreros: Foreign-Born Engineers and Scientists in the HighTechnology Industry of Silicon Valley.” In Immigration Research for a New Century, Multidisciplinary Perspectives. Ed. N. Foner, R. G. Rumbaut and S. J. Gold. New York: Russell Sage Foundation. Pp. 301-321.

1999 "Recruitment Processes Among Foreign-Born Engineers and Scientists in Silicon Valley," American Behavioral Scientist, 42:1381-1397.

Allison, P. D.

1977 “Testing for Interaction in Multiple Regression,” American Journal of Sociology, 83:144-153.

Bailey, T. and R. Waldinger

1991 "Primary, Secondary, and Enclave Labor Markets: A Training Systems Approach," American Sociological Review, 56:432-445.

Baker, S. G.

1997 "The "Amnesty" Aftermath: Current Policy Issues Stemming from the Legalization Programs of the 1986 Immigration Reform and Control Act," International Migration Review, 31:5-27.

1996 Voto Es Su Voz: Latino Political Empowerment and the Immigration Challenge," Political Science and Politics, 29:465-468.

Bayer, A. E.

1968 "The Effects of International Interchange of High-Level Manpower on the United States," Social Forces, 46:465-477.

Bean, F. D. and G. Stevens

2003 America's Newcomers and the Dynamics of Diversity. New York: Russell Sage Foundation.

Bean, F. D., E. E. Telles and L. Lowell

1987 "Undocumented Migration to the United States: Perceptions and Evidence," Population and Development Review, 13:671-690.

Bean, F. D. and M. Tienda

1987 Hispanics in the United States. New York: Russell Sage Foundation. 
Bean, F. D., B. L. Lowell and L. J. Taylor

1988 "Undocumented Mexican Immigrants and the Earnings of Other Workers in the United States," Demography, 25:35-52.

Becker, G. S.

1975 Human Capital: A Theoretical and Empirical Analysis, with Special Reference to Education. New York: Columbia University Press.

1962 "Investment in Human Capital: A Theoretical Analysis," Journal of Political Economy, 70:949.

Blalock, H. M. Jr.

1965 "Theory Building and the Statistical Concept of Interaction," American Sociological Review, 30:374-380.

Bonacich, E.

1973 “A Theory of Middleman Minorities," American Sociological Review, 38:583-594.

1972 "A Theory of Ethnic Antagonism: The Split Labor Market," American Sociological Review, 37:547-549.

Borjas, G. J.

2000 Issues in the Economics of Immigration. Chicago, IL: University of Chicago Press.

1999 Heaven's Door: Immigration Policy and the American Economy. Princeton, N.J.: Princeton University Press.

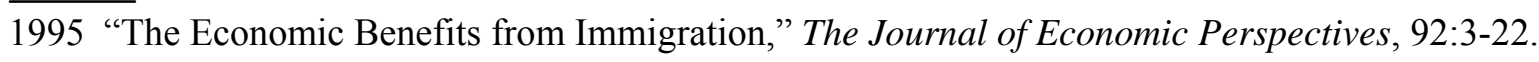

1994 “The Economics of Immigration,” Journal of Economic Literature, 32:1667-1717.

1990 Friends or Strangers: The Impact of Immigrants on the U.S. Economy. New York: Basic Books.

1987 “Immigrants, Minorities, and Labor Market Competition," Industrial and Labor Relations Review, 40:382-392.

1986 "The Self-Employment Experience of Immigrants," Journal of Human Resources, 21:485-506.

1983-1984 "The Labor Supply of Male Hispanic Immigrants in the United States," International Migration Review, 17: 653-671. 
1983. "The Labor Supply of Male Hispanic Immigrants in the United States," International Migration Review, 17:653-671.

Borjas, G. J. and R. B. Freeman

1992 Immigration and the Work Force: Economic Consequences for the United States and Source Areas. Chicago, IL: University of Chicago Press.

Borjas, G. J. and M. Tienda

1993 "The Employment and Wages of Legalized Immigrants," International Migration Review, 27:712-747.

1987a "The Economic Consequences of Immigration," Sciences, 645-651.

1987 b "Immigrants, Minorities, and Labor Market Competition," Industrial and Labor Relations Review, 40:382-392.

Borowski, A.

1984 "A Comparison of Youth Unemployment in Australia and the United States," Monthly Labor Review, 107:30-36.

Bradshaw, B. and W. P. Frisbie

1983 "Potential Labor Force Supply and Replacement in Mexico and the States of the Mexican Cession and Texas: 1980-2000," International Migration Review, 17:394-409.

Briggs, V. M, Jr.

1983 "Illegal Immigration from Mexico and Its Labor Force Implications," ILR Report, 20:612.

Brown, S. and J.G. Sessions

1997 “A Profile of UK Unemployment: Regional Versus Demographic Influences," Regional Studies, 31:351-366.

Bustamante, J. A.

1997 “Mexico-United States Labor Migration Flows," International Migration Review, 31:11121121.

1976 "Structural and Ideological Conditions of the Mexican Undocumented Immigration to the United States," American Behavioral Scientist, 19:364-376.

Cain, G. G.

1975 "The Challenge of Dual and Radical Theories of the Labor Market to Orthodox Theory," The American Economic Review, 65:16-22.

Castells, M.

1996 The Rise of the Network Society. Cambridge, MA: Blackwell. 
Chapa, J.

1990 "The Myth of Hispanic Progress: Trends in the Educational and Economic Attainment of Mexican Americans," Journal of Hispanic Policy, 4:3-18.

Chavez, L.

1991 Out of the Barrio: Toward a New Politics of Hispanic Assimilation. New York: Basic Books.

Chiswick, B. R.

1986 "Mexican Immigrants: The Economic Dimension," Annals of the American Academy of Political and Social Science, 487:92-101.

1978 "The Effect of Americanization on the Earnings of Foreign-Born Men," Journal of Political Economy, 86:897-921.

Chiswick, B. R, Y. Cohen and T. Zach

1997 "The Labor Market Status of Immigrants: Effects of the Unemployment Rate at Arrival and Duration of Residence," Industrial and Labor Relations Review, 50:289-303.

Clark, W. A. V.

1998 "Mass-Migration and Local Outcomes: Is International Migration to the United States Creating a New Urban Underclass?," Urban Studies, 35:371-383.

Clogg, C. C. and J. W. Shockey

1985 "The Effect of Changing Demographic Composition on Recent Trends in Underemployment," Demography, 22:395-414.

Cohen, Y.

1989 "Socioeconomic Dualism: The Case of Israeli-Born Immigrants in the United States," International Migration Review, 23:267-288.

Cornelius, W. A.

1981 "The Future of Mexican Immigrants in California: A New Perspective for Public Policy," Research Report Series, No. 6. La Jolla, CA: UC San Diego, Center for United States-Mexican Studies.

Davila, A. and M. T. Mora

2000 "English Fluency of Recent Hispanic Immigrants to the United States in 1980 and 1990," Economic Development and Cultural Change, 48:369-389.

Davila, A., J. A. Pagan and M. V. Grau

1998 "The Impact of IRCA on the Job Opportunities and Earnings of Mexican-American and Hispanic-American Workers," International Migration Review, 32:79-95.

Dominguez, J. and R. Fernandez de Castro

2001 The United States and Mexico: Between Partnership and Conflict. New York: Routledge.

Donato, K. M. and D. S. Massey

1993 "Effect of the Immigration Reform and Control Act on the Wages of Mexican Migrants," Social Science Quarterly, 74:523-541. 
Donato, K. M., J. Durand and D. S. Massey

1992a "Changing Conditions in the US Labor Market: Effects of the Immigration Reform and Control Act of 1986," Population Research and Policy Review, 11:93-115.

1992b "Stemming The Tide? Assessing the Deterrent Effects of the Immigration Reform and Control Act," Demography, 29:139-157.

Durand, J., D. S. Massey and F. Charvet

2000 "The Changing Geography of Mexican Immigration to the United States: 1910-1996," Social Science Quarterly, 81:1-15.

Edwards, R. C., M. Reich and D. M. Gordon

1975 Labor Market Segmentation [paper] Conference on Labor Market Segmentation (1973: Harvard University). Lexington, MA: D.C. Heath.

Enchautegui, M. E.

1998 "Low-skilled Immigrants and the Changing American Labor Market," Population and Development Review, 24:811-824.

Espenshade, T. J.

1995 "Unauthorized Immigration to the United States," Annual Review of Sociology, 21:195-216.

Espenshade, T. J. and V. E. King

1994 "State and Local Fiscal Impacts of U.S. Immigrants: Evidence from New Jersey." Population Research and Policy Review, 13:209-240.

Espinosa, K. E. and D. S. Massey

1997 "Determinants of English Proficiency among Mexican Migrants to the United States," International Migration Review, 31:28-50.

Fairlie, R. W. and B. D. Meyer

1996 "Ethnic and Racial Self-Employment Differences and Possible Explanations," The Journal of Human Resources, 31:757-793.

Freeman, R. B.

1979. "The Effect of Demographic Factors on Age-Earnings Profiles," The Journal of Human Resources, 14:289-318.

Frienberg, R. M. and J. Hunt

1995 "The Impact of Immigrants on Host Country Wages, Employment and Growth," The Journal of Economic Perspectives, 9:23-44.

Gordon, D. M.

1972 Theories of Poverty and Underemployment: Orthodox, Radical, and Dual Labor Market Perspectives. Lexington, Mass.: Lexington Books.

Grebler, L.

1966 "The Naturalization of Mexican Immigrants in the United States," International Migration Review, 1:17-32. 
Gurak, Douglas T. and Fe Caces

1992 "Migration Networks and the Shaping of Migration Systems." In International Migration Systems: A Global Approach. Ed. M. M. Kritz, L. L. Lim and Hania Zlotnick. Oxford: Clarendon Press. Pp. 150-176.

Hansen, N. and G. Cardenas

1988 "Immigrant and Native Ethnic Enterprises in Mexican American Neighborhoods: Differing Perceptions of Mexican Immigrant Workers,” International Migration Review, 22:226-242.

Heer, D. M.

1990 Undocumented Mexicans in the United States. New York: Cambridge University Press.

Holzer, H.

1998 "Search Methods Used by Unemployed Youth,” Journal of Labor Economics, 6:1-20.

Huber, G. A. and T. J. Espenshade

1997 "Neo-Isolationism, Balanced-Budget Conservatism, and the Fiscal Impacts of Immigrants," International Migration Review, 31:1031-1054.

Huddle, D. L.

1993 "Dirty Work: Are Immigrants Only Taking Jobs That the Native Underclass Does Not Want?," Population and Environment, 14:515-38.

Hughes, P. R. and G. Hutchinson

1988 "Unemployment, Irreversibility and the Long-term Unemployed." In Unemployment, Hysteresis and the Natural Rate Hypothesis. Ed. R. Cross. Oxford: Blackwell. Pp.79-98.

Jargowsky, P. A.

1997 Poverty and Place: Ghettos, Barrios, and American City. New York: Russell Sage Foundation.

Jasso, G. and M. R. Rosenzweig

1990 The New Chosen People: Immigrants in the United States. New York: Russell Sage.

1985 What's in a Name? Country-of-Origin Influences on the Earnings of Immigrants in the United States. Bull. \#85-4, Minneapolis: Econ. Dev. Ctr., Univ. Minn. (Mimeo)

Jenkins, J. C.

1977 "Push/Pull in Recent Mexican Migration to the U.S," International Migration Review, 11:178189.

Jensen, L.

1988 "Patterns of Immigration and Public Assistance Utilization, 1970-1980," International Migration Review, 22:51-83.

Johnson, J. H., Jr. and M. L. Oliver 1989 "Interethnic Minority Conflict in Urban America: The Effects of Economic and Social Dislocations," Urban Geography, 10:449-463.

Juhn, C., K. M. Murphy and B. Pierce

1993 "Wage Inequality and the Rise in Returns to Skill." Journal of Political Economy. 101:410-442. 
Kalleberg, A. L. and A. B. Sorensen

1979 "The Sociology of Labor Markets," Annual Review of Sociology, 5:351-379.

Kandel, W. and J. Cromartie

2003. "New Patterns of Hispanic Settlement in Rural America." Rural Development Research Report Number 99. United States Department of Agriculture. Economic Research Service.

Keely, C. B.

1974 "Immigration Composition and Population Policy," Science, 185:587-593.

Kleinbaum, D. G. and L. L. Kupper

1978 Applied Regression Analysis and Other Multivariable Methods. North Scituate, MA: Duxbury Press.

Kossoudji, S.

1989 "Immigrant Worker Assimilation: Is It a Labor Market Phenomenon?" The Journal of Human Resources, 24:494-527.

Krissman, F.

2000 "Immigrant Labor Recruitment: U.S. Agribusiness and Undocumented Migration from Mexico." In Immigration Research for a New Century. Ed. N. Foner, R. Rumbaut and S. Gold. New York: Russell Sage.

Kritz, M. M.

1987 “International Migration Policies: Conceptual Problems," International Migration Review, 21:947-964.

Kritz, M. M. and J. M. Nogle

1994 "Nativity Concentration and Internal Migration among the Foreign-Born," Demography, 31:509-524.

Kurthen, $\mathrm{H}$.

1997 "Immigration and the Welfare State in Comparison: Differences in the Incorporation of Immigrant Minorities in Germany and the United States." International Migration Review. 31: 721-731.

Lacy, G., C. Johnson and D. Heffeman.

1989 Tackling the Youth Employment Problem. Washington, D.C.: Children's Defense Fund.

Layard, R., S. Nickell and R. Jackman

1991 Unemployment, Macroeconomic Performance and the Labor Market. Oxford: Oxford University Press.

Lee, E. S.

1966 “A Theory of Migration,” Demography, 3:47-57.

Liang, Z.

1994 "On the Measurement of Naturalization," Demography, 31:525-548. 
Lien, P.

1994 "Ethnicity and Political Participation: A Comparison between Asian and Mexican Americans," Political Behavior, 16:237-264.

Light, I., G. Sabagh, M. Bozorgmehr and C. Der-Martirosian

1994 "Beyond the Ethnic Enclave Economy," Social Problems, 41:65-80.

Logan, J. R., R. D. Alba and T. L. McNulty

1994 "Ethnic Economies in Metropolitan Regions: Miami and Beyond," Social Forces, 72:691-724.

McConnell, E. D. and F. B. Leclere

2002 "Selection, Context, or Both? The English Fluency of Mexican Immigrants in the American Midwest and Southwest," Population Research and Policy Review, 21:179-204.

Madhavan, M.C.

1985 "Indian Emigrants: Numbers, Characteristics, and Economic Impact," Population and Development Review, 11:457-481.

Marcelli, E. A and W. A. Cornelius

2001 "The Changing Profile of Mexican Migrants to the United States: New Evidence from California and Mexico," Latin American Research Review, 36:105-131.

Marshall, R.

1987 "Controlling Illegal Immigration," In Hearings before the Joint Economic Committee, Economic and Demographic Consequences of Immigration. Washington, D.C.: US Government Printing Office. Pp. 21-46.

1984 "Immigration: An International Economic Perspective," International Migration Review, 18:593-612.

Martin, P.

1995 “Proposition 187 in California," International Migration Review, 29: 255-263.

2000 "Migration and Development: the Mexican-US Case," Symposium on International Migration in the Americas, ECLAC (Economic Commission for Latin America and the Caribbean) IOM (International Organization for Migration), San Jose, Costa Rica: 1-17.

Massey, D. S.

2001 "Theory of Migration," In International Encyclopedia of the Social and Behavioral Sciences. Ed. N. J. Smelser and P. B. Baltes. Elsevier Science Ltd. Pp. 9828-9834.

1996 "The Age of Extremes: Concentrated Affluence and Poverty in the Twenty-First Century," Demography, 33:395-412.

1987a "Do Undocumented Migrants Earn Lower Wages than Legal Immigrants? New Evidence from Mexico,” International Migration Review, 21:1498-1522. 
1987b "Understanding Mexican Migration to the United States," The American Journal of Sociology, 92: 1372-1403.

Massey, D. S. and K. E. Espinosa

1997 "What's Driving Mexico-U.S. Migration? A Theoretical, Empirical, and Policy Analysis," The American Journal of Sociology, 102:939-999.

Massey, D. S. and K. M. Schnabel

1983 "Recent Trends in Hispanic Immigration to the United States," International Migration Review, $17: 212-244$

Massey, D. S., J. Arango, G. Hugo, A. Kouaouci, A. Pellegrino and J. E. Taylor

1994 "An Evaluaiton of International Migration Theory: The North American Case," Population and Development Review, 20:699-751.

1993 "Theories of International Migration: A Review and Appraisal," Population and Development Review, 19:431-466.

Massey, D. S. and K. E. Espinona

1997 "What's Driving Mexico-U.S. Migration? A Theoretical, Empirical, and Policy Analysis," The American Journal of Sociology, 102:939-999.

Massey, D. S., A. B. Gross, and K. Shibuya

1994 "Migration, Segregation, and the Geographic Concentration of Poverty," American Sociological Review, 59:425-445.

McCall, L.

2000a “Explaining Levels of Within-Group Wage Inequality in U.S. Labor Markets,” Demography, $37: 415-430$.

2000b "Gender and the New Inequality: Explaining the College/Non-College Wage Gap," American Sociological Review, 65:234-255.

Meisenheimer II, J. R.

1992 “How Do Immigrants Fare in the U.S. Labor Market?” Monthly Labor Review, 115:3-19.

Melendez, E., C. Rodriguez and J. B. Figueroa

1991 Hispanics in the Labor Force: Issues and Policies. New York: Plenum Press.

Mincer, J.

1974 Schooling, Experience, and Earnings. New York: National Bureau of Economic Research (Distributed by Columbia University Press).

Model, S.

1992 "The Ethnic Economy: Cubans and Chinese Reconsidered," Sociological Quarterly, 33:63-82.

Moore, J. and H. Pachon

1985 Hispanics in the United States. Englewood Cliff, NJ: Prentice-Hall. 
Morales, R., and P. M. Ong

1993 "The Illusion of Progress: Latinos in Los Angeles," In Latinos in a Changing U.S. Economy: Comparative Perspectives on Growing Inequality. Ed. R. Morales and F. Bonilla. Newbury Park, CA: Sage.

Nee, V. and J. M. Sanders

1987 “On Testing the Enclave-Economy Hypothesis," American Sociological Review, 52:771-773.

Nonini, D. and A. Ong

1997 "Chinese Transnationalism as an Alternative Modernity." In Ungrounded Empires: The Cultural Politics of Modern Chinese Transnationalism. Ed. A. O. and D. Nonini. New York: Routledge.

Oi. W.

1962 “Labor as Quasi-fixed Factor,” Journal of Political Economics, 70:538-55.

Osberg, L., R. Apostle and D. Clairmont

1986 "The Incidence and Duration of Individual Unemployment: Supply Side or Demand Side?" Cambridge Journal of Economics, 10:13-33.

Pellegrino, A.

2001 "Trends in Latin American Skilled Migration: "Brain Drain" or "Brain Exchange"?" International Migration Review, 39:111-132.

Pett, M. A., N. R. Lackey and J. J. Sullivan

2003 Making Sense of Factor Analysis: The Use of Factor Analysis for Instrument Development in Health Care Research. Thousand Oaks, CA: Sage Publications.

Phillips, J. A. and D. S. Massey

1999 "The New Labor Market: Immigrants and Wages after IRCA,” Demography, 36:233-246.

Piore, $\mathrm{M}$.

1979 Birds of Passage: Migrant Labor and Industrial Societies. Cambridge, NY: Cambridge University Press.

Pissarides, C. and J. Wadsworth

1990 "Who Are the Unemployed?" Discussion Paper No. 12, Center for Economic Performance. London School of Economics.

Portes, A.

1981 "Modes of Structural Incorporation and Present Theories of Immigration." In Global Trends in Migration. Ed. M. M. Kritz, C. B. Keely and S. M. Tomasi. Staten Island, NY: CMS Press. Pp. 279-297.

Portes, A. and R. L. Bach

1985 The Latin Journey: Cuban and Mexican Immigrants in the United States. Berkeley, CA: University of California Press.

1980 "Immigrant Earnings: Cuban and Mexican Immigrants in the United States," International Migration Review, 14:315-341. 
Portes, A. and L. Jensen

1992 "Disproving the Enclave Hypothesis: Reply," American Sociological Review, 57:418-420.

1989 "The Enclave and the Entrants: Patterns of Ethic Enterprise in Miami before and after Mariel," American Sociological Review, 54:929-949.

Portes, A. and C. Truelove

1987 "Making Sense of Diversity: Recent Research on Hispanic Minorities in the United States," Annual Review of Sociology, 13:359-385.

Portes, A. and M. Zhou

1996 "Self-Employment and the Earnings of Immigrants," American Sociological Review, 61:219230.

1993 "The New Second Generation: Segmented Assimilation and Its Variants," The Annals of the American Academy of Political and Social Sciences, 530:74-96.

Portes, A. and R. Mozo

1985 "The Political Adaptation Process of Cuban and Other Ethnic Minorities in the United States: A Preliminary Analysis," International Migration Review, 19:35-63.

Purcell, S. K.

1997 "The Changing Nature of US-Mexican Relations," Journal of Interamerican Studies and World Affairs, 39:137-152.

Ramsey, F. L. and D. W. Schafer

1997 The Statistical Sleuth: A Course in Methods of Data Analysis. Belmont, CA: Duxbury Press.

Reed, D.

2001 "Immigration and Males' Earnings Inequality in the Regions of the United States," Demography, 38:363-373.

Reitz, J. G., L. Calzavara and D. Dasko

1981 "Ethnic Inequality and Segregation in Jobs." Research Paper No. 123. Toronto: Center for Urban and Community Studies, University of Toronto.

Roberts, B. R., R. Frank and F. Lozano-Ascencio

1999 "Transnational Migrant Communities and Mexican Migration to the US," Ethnic and Racial Studies, 22:238-266.

Rones, P. L.

1983 “The Labor Market Problems of Older Workers," Monthly Labor Review, 106:3-12.

Roos, P. A. and J. F. Hennessy

1987 "Assimilation or Exclusion? Japanese and Mexicans in California," Sociological Forum, 2:278304. 
Ruiz-Quintanilla, S. A. and R. Claes

1996 "Determinants of Unemployment of Young Adults: A Multi-Country Study," Industrial and Labor Relations Review, 49:424-438.

Saenz, R.

2004a "The Demography of Latino Immigration: Trends and Implications for the Future." Paper presented at the American Sociological Association Congressional Briefing on Immigration. Washington, D.C.

2004b The American People: Latinos and the Changing Face of America. New York: Russell Sage Foundation.

1999 "Mexican Americans." In The Minority Report: An Introduction to Racial, Ethnic, and Gender Relations. Ed. A. G. Dworkin and R. J. Dworkin. Fort Worth, TX. Holt, Rinehart, and Winston. Pp. 209-229.

1991 "Interregional Migration Patterns of Chicanos: The Core, Periphery, and Frontier," Social Science Quarterly, 72:135-148.

Saenz, R. and C. C. Torres

2003 "Latinos in Rural America." In Challenges for Rural American in the Twenty-First Century. Ed. D. L. Brown and L. E. Swanson. University Park, PA: Pennsylvania State University Press, Rural Studies Series. Pp. 57-70.

Saenz, R. and M. C. Morales

2005 "Demography of Race and Ethnicity." In the Handbook of Population. Ed. Poston, D. L. Jr. and M. Micklin. New York: Klewer Academic/Plenum Publishers.

Sakamoto, A. Jr. and M. D. Chen

1991 "Inequality and Attainment in a Dual Labor Market," American Sociological Review, 56:295308.

Sakamoto, A. Jr., H. Wu and J. M. Tzeng

2000 "The Declining Significance of Race among American Men during the Latter Half of Twentieth Century," Demography, 37:41-51.

Sanchez, G. J.

1997 "Face the Nation: Race, Immigration, and the Rise of Nativism in Late Twentieth Century America." International Migration Review. 31: 1009-1030.

Sanders, J. M. and V. Nee

1996 "Immigrant Self-Employment: The Family as Social Capital and the Value of Human Capital." American Sociological Review. 61-2: 231-249.

1992 "Problems in Resolving the Enclave Economy Debate," American Sociological Review, 57:415-418. 
1987 "Limits of Ethnic Solidarity in the Enclave Economy," American Sociological Review, 52:745773.

Sandos, J. A. and H. E. Cross.

1983 "National Development and International Labour Migration: Mexico 1940-1965," Journal of Contemporary History, 181:43-60.

Saxenian, A.

1996 Regional Advantage: Culture and Competition in Silicon Valley and Route 128. Cambridge, MA: Harvard University Press.

Schoeni, R.F.

1998 "Labor Market Outcomes of Immigrant Women in the United States: 1970 to 1990," International Migration Review, 32:57-77.

Schultz, T. W.

1961 "Investment in Human Capital," The American Economic Review, 51:1-17.

Sehgal, E.

1985 "Foreign Born Workers in the U.S. Labor Market: The Results of a Special Survey," Monthly Labor Review, 108:18-24.

Semyonov, M.

1988 "Bi-Ethnic Labor Markets, Mono-Ethnic Labor Markets, and Socioeconomic Inequality," American Sociological Review, 53:256-266.

Simon, J. L. and R. J. Sullivan

1988 “More on Immigrants' Earnings Over Time," Genus, 44:157-173.

Simon, J. L., S. Moore and R. J. Sullivan

1993 "The Effect of Immigration on Aggregate Native Unemployment: An Across-City Estimation," Journal of Labor Research, 14:299-316.

Smith, J. P.

1984 "Race and Human Capital," American Economic Review, 74:685-698.

Sorensen, E. and F. D. Bean

1994 "The Immigration Reform and Control Act and the Wages of Mexican Origin Workers: Evidence From Current Population Surveys," Social Science Quarterly, 75:1-17.

Spencer, D. and F. D. Bean

1999 "Self-Employment Concentration and Earnings among Mexican Immigrants in the U.S.," Social Forces, 77:1021-1047.

Stevens, G.

1992 "The Social and Demographic Context of Language Use in the United States," American Sociological Review, 57:171-185. 
Stolzenberg, R. M.

1990 "Ethnicity, Geography and Occupational Achievement of Hispanic Men," American Sociological Review, 55:143-154.

Suro, Robert., and Audrey Singer

2002 "Latino Growth in Metropolitan America: Changing Patterns, New Locations." Washington, DC: Center on Urban and Metropolitan Policy, The Brookings Institution and The Pew Hispanic Center.

Taylor L. J., F. D. Bean, J. B. Rebitzer, S. G. Baker and B L. Lowell

1988 "Mexican Immigrants and the Wages and Unemployment Experience of Native Workers.” Washington, D.C., Urban Institute, 1988 Sep. 19 p. Program for Research on Immigration Policy Discussion Paper No. PRIP-Ul-1.

Tickamyer, A. R. and J. Bokemeier

1993 "Alternative Strategies for Labor Market Analyses: Multi-Level Models of Labor Market Inequality." In Inequalities in Labor Market Areas. Ed. J. Singelmann and F. A. Deseran. Boulder, CO: Westview Press. Pp. 49-68.

Tienda, $\mathrm{M}$.

2002 "Demography and the Social Contract," Demography, 39: 587-616.

1983 "Market Characteristics and Hispanic Earnings: A Comparison of Natives and Immigrants," Social Problems, 31:59-72.

Tienda, M. and D. Lii

1987 "Minority Concentration and Earnings Inequality: Blacks, Hispanics, and Asians Compared," American Journal of Sociology, 93:141-165.

Tolbert, C. J. and R. E. Hero

1996 "Race/Ethnicity and Direct Democracy: An Analysis of California's Illegal Immigration Initiative," The Journal of Politics, 58:806-818.

Topel, R. H.

1994 "Regional Labor Markets and the Determinants of Wage Inequality," The American Economic Review, 84:17-22.

Trejo, S. J.

1997 “Why Do Mexicans Earn Low Wages,” The Journal of Political Economy, 105:1235-1268.

Valdes, D. N.

1995 "Legal Status and the Struggle of Farmworkers in West Texas and New Mexico, 1942-1993," Latin American Perspectives, 22:117-137.

Waldinger, R.

1994 "The Making of an Immigrant Niche," International Migration Review, 28:3-30.

1989a "Immigration and Urban Change," Annual Review of Sociology, 15:211-232. 
1989 b "Structural Opportunity or Ethnic Advantage? Immigrant Business Development in New York," International Migration Review, 23:48-72.

1986 "Immigrant Enterprise: A Critique and Reformation," Theory and Society, 15:249-285.

Wallace, S. P.

1986 "Central American and Mexican Immigrant Characteristics and Economic Incorporation in California," International Migration Review, 20:657-671.

Williams, H. M.

1991 “1986 Law Hasn’t Cut Numbers of Undocumented Aliens,” El Paso Times. January 11.

Wilson, K. L. and A. Portes

1980 "Immigrant Enclaves: An Analysis of the Labor Market Experiences of Cubans in Miami," The American Journal of Sociology, 86:295-319.

Wilson, K. and W. A. Martin

1982 "Ethnic Enclaves: A Comparison of the Cuban and Black Economies of Miami," American Journal of Sociology, 88:135-160.

Winegarden, C. R. and L. B. Khor

1991 "Undocumented Immigration and Unemployment of U.S. Youth and Minority Workers: Econometric Evidence," Review of Economics and Statistics, 73:105-112.

Wright, R., M. Ellis and M. Reibel

1997 "The Linkage between Immigration and Internal Migration in Large Metropolitan Areas in the United States," Economic Geography, 73:234-254.

Zhou, M. and J. R. Logan

1989 "Returns to Human Capital in Ethnic Enclaves: New York City's Chinatown," American Sociological Review, 54:809-820.

Zucker, L. G. and C. Rosenstein

1981 “Taxonomies of Institutional Structure: Dual Economy Reconsidered," American Sociological Review, 46:869-884. 


\section{APPENDIX}

\section{INTERACTION EFFECTS}

The literature shows that immigrant status and naturalization status have an effect on the degree that human capital affects wages. In fact, sociological theories often imply that a linear association between a predictor and a dependent variable is affected by the third variable (Blalock, 1965; Aiken and West, 1991). For example, a linear association between the natural logarithm of the hourly wage and education may differ depending on a Mexican worker's English language proficiency. Interaction is a term in a statistical model in which the effect of two or more independent variables is not simply additive. Testing for the presence of interaction is one way to reduce the effects of unexplained variables. The interaction is tested by including a cross-product term of $x_{1}$ and $x_{2}$ under consideration (e.g., English language proficiency and education) in a multiple regression (Allison, 1977). Thus, for a response variable $y$ and two independent variables $x_{1}$ and $x_{2}$ an additive model would be:

$y=a x_{1}+b x_{2}+$ error,

while

$y=a x_{1}+b x_{2}+c\left(x_{1} \times x_{2}\right)+$ error, is an example of a model with an interaction between variables $x_{1}$ and $x_{2}$.

The interaction term in the full model (all variables included in the model plus an interaction term) tests the following null and alternative hypotheses:

$\mathrm{H}_{0}: \beta_{1}=\beta_{2}=\beta_{3}=\cdots=\beta_{\mathrm{k}}$ (all slopes are equal, or linear relations between the outcome variable and independent variable are same across values of a third variable).

Ha: at least one slope differs. 
If the t-value for the interaction is significant, or if the null hypothesis is rejected, we assume that slopes are not equal, and thus there is interaction. If we fail to reject the null hypothesis, we assume equal slopes and drop the interaction term (there is not significant evidence that the change is not the same for the slopes). This model is called "reduced model" or "parallel line model" as we refit the model without interaction.

The analysis of human capital attributes and other factors shows that metropolitan area residence, employment in management, professional and related occupations, Englishlanguage ability and education are strong factors associated with higher wage returns. Therefore, I examine whether the linear associations between the natural logarithm of the hourly wage and these variables differ based on the nativity difference and immigrants' possession of U.S. citizenship. Namely, the following interactions are tested: (1) immigrant status and metropolitan area residence (imm*metrores) and (2) immigrant status and management, professional and related occupations (imm*mgrprorl) in Model 1A and 1B, and (3) self-reported English language proficiency and education (engabil*somehs, engabil*hsgrad, engabil*somecoll, and engabil*collgrad), (4) non-naturalization status and metropolitan area residence (nocit*metrores), and (5) non-naturalization status and management, professional and related occupations (nocit*mgrprorl) in Model 2A and 2B. However, two of the interaction terms, imm*metrores and nocit*mgrprorl are dropped from the models as they have strong collineality with imm and nocit, respectively, and thus make these two interaction terms statistically insignificant. Selected findings are presented below and in Table 12.

Regarding imm*mgrprorl $(\mathrm{t}=-3.69, \mathrm{p}<0.0002$ in Model $1 \mathrm{~A}$ and $\mathrm{t}=-3.07, \mathrm{p}<$ 0.0021 in Model 1B), the wage difference between foreign-born and native-born (imm) 
Table 12. Selected Results of Interaction Tests

\begin{tabular}{|l|c|c|}
\hline & California & Texas \\
\hline $\begin{array}{l}\text { Cost of being a Mexican immigrant employed in } \\
\text { management, professional, and related } \\
\text { occupations }\end{array}$ & $9 \%^{* *}$ & $5 \%^{*}$ \\
\hline $\begin{array}{l}\text { Wage penalty of Mexican immigrants who have } \\
\text { high school diploma but do not speak English }\end{array}$ & $17 \%^{* *}$ & $11 \%$ \\
\hline $\begin{array}{l}\text { Wage penalty of Mexican immigrants who have } \\
\text { bachelor's degree but do not speak English }\end{array}$ & $48 \%^{* * *}$ & $50 \%^{* * *}$ \\
\hline $\begin{array}{l}\text { The cost of being a Mexican non-citizen in } \\
\text { metropolitan areas }\end{array}$ & $17 \%^{* * *}$ & $13 \%^{* *}$ \\
\hline
\end{tabular}

***Significant at the 0.0001 level.

**Significant at the 0.0005 level.

*Significant at the 0.005 level.

Source: 2000 5\% PUMS.

employed in management, professional and related occupations (mgrprorl) are estimated. In Model 1A, when the person is a foreign-born worker $(\mathbf{i m m}=1)$ employed in management, professional, and related occupations (mgrprorl $=1)$, lghrwage $=1.13468($ intercept $)+0.46655($ mgrprorl $)-0.05630(\mathbf{i m m})-0.03171$ $($ imm*mgrprorl $)=1.51322$, and when the person is a native-born worker ( $(\mathbf{m m}=0$ ) employed in management, professional, and related occupations (mgrprorl $=1)$, lghrwage $=1.13468($ intercept $)+0.46655($ mgrprorl $)+0(\mathbf{i m m})+0(\mathbf{i m m} *$ mgrprorl $)=$ 1.60123 $\exp ^{1.60123-1.51322}=\exp ^{0.08801}=1.0920$ 
In California, a Mexican immigrant who is employed in management, professional and related occupations has a 9 percent lower hourly wage than a native-born Mexican American who is employed in this occupational category.

In Model 1B, on the other hand, an immigrant who is employed in this occupational category has a 5 percent lower hourly wage than a native-born employed in this occupational category: when the person is a foreign-born worker $(\mathbf{i m m}=1)$ employed in management, professional, and related occupations $($ mgrprorl $=1)$, lghrwage $=1.09299($ intercept $)+0.46639($ mgrprorl $)-0.01191(\mathbf{i m m})-0.03628$ $($ imm*mgrprorl $)=1.51119$, and when the person is a native-born worker $(\mathbf{i m m}=0)$ employed in management, professional, and related occupations (mgrprorl $=1)$, lghrwage $=1.09299($ intercept $)+0.46639(\mathbf{m g r p r o r l})+0(\mathbf{i m m})+0(\mathbf{i m m} * \mathbf{m g r p r o r l})=$ 1.55938

$\exp ^{1.55938-1.51119}=\exp ^{0.04819}=1.0494$

These wage differences (9\% in Model $1 \mathrm{~A}$ and $5 \%$ in $1 \mathrm{~B})$ are statistically significant because the interaction term imm*mgrprorl is statistically significant. The interaction test shows that being employed in management, professional, and related occupations does not cancel the cost of being an immigrant across both states, confirming the major argument of this study that being an immigrant is a central factor associated with internal wage gaps within the Mexican-origin population.

Five interaction terms included in the immigrant-only sample are assessed in the same manner, and three selected findings are reported. Regarding the engabil*hsgrad interaction in Model 2A, immigrants who speak English and whose highest educational attainment is 
high school graduation $($ engabil $=1$ and hsgrad $=1)$ have 17 percent $\left(\exp ^{0.15603}\right)$ higher wages than immigrants whose highest educational attainment is high school graduation but do not speak English (engabil $=0$ and hsgrad $=1)$. However, the variable is not statistically significant in Model 2B $(\mathrm{t}=1.16, \mathrm{p}=0.2457)$.

Regarding the engabil*collgrad variable in Model 2A, immigrants who speak English and whose highest educational attainment is college completion (engabil $=1$ and collgrad $=1)$ have 48 percent $\left(\exp ^{0.39192}\right)$ higher wages than immigrants whose highest educational attainment is college completion but do not speak English (engabil $=0$ and collgrad $=1)$. Model 2B also shows a similar pattern; immigrants who speak English and whose highest educational attainment is college completion have 50 percent $\left(\exp ^{0.40613}\right)$ higher wages than immigrants whose highest educational attainment is college completion but do not speak English. The interaction test shows that wage returns to education are significantly affected by the immigrant's English language ability.

The last interaction term included in the immigrant-only models is nocit*metrores. Descriptive statistics (Table 2) shows that about 90 percent of the naturalized citizens and non-naturalized citizens were metropolitan area residents in California. In Texas, 67 percent of naturalized citizens and 75 percent of non-naturalized citizens were metropolitan area residents. As metropolitan area residence is positively associated with hourly wages, I assess the different effect of metropolitan area residence on wages between naturalized citizens and non-naturalized citizens. In Model 2A, non-citizens $($ nocit $=1)$ in metropolitan areas $($ metrores $=1)$ have 17 percent $\left(\exp ^{0.15745}\right)$ lower wages than naturalized citizens in metropolitan areas. In Model 2B, on the other hand, non-citizens in metropolitan areas have 13 percent $\left(\exp ^{0.11795}\right)$ lower wages than naturalized citizens in metropolitan areas. These 
results indicate that residing in metropolitan areas does not cancel the cost of being a noncitizen both in California and Texas.

The results support the literature discussing that immigrant status and naturalization status have an effect on the degree that human capital affects wages. Mexican immigrants with the same types of occupations as native-born Mexican Americans attain lower wages than their native-born counterparts. The same is true of language ability; those who speak English attain higher wages than their non-English-speaking, but equally well-educated counterparts. It is likely that the ability to speak English is also an important status marker. The results of interaction tests confirm the major argument of this study that being a foreignborn and being a non-citizen are the two major factors of the internal wage gaps among the Mexican-origin workers. 


\section{VITA}

Name: Isao Takei

Address: Department of Sociology, Mail Stop 4351, Texas A\&M University, College Station, TX, 77843-4351

Email Address: isaotakei@neo.tamu.edu

Education: B.A., International Relations, Nihon University, 1999

M.A., International Relations, Nihon University, 2002

M.S., Sociology, Texas A\&M University, 2005

Publications: Isao Takei. 2001. "Proposition 227 and a Wave of Immigrants in California." Graduate Research Studies in International Relations. 11: 175-191.

Saburo Sato, Isao Takei and Jon P. Alston. 2003. "White Anglo-Saxon Mythology and Intersection of Race, Class, and Gender in the Titanic." Studies of International Relations. 24-2: 15-42.

Jon P. Alston and Isao Takei. 2005. Japanese Business Culture and Practices: A Guide to Twenty First Century Japanese Business. Lincoln, NE: iUniverse.

Isao Takei. 2005. "Issues of Scope in Comparative Race and Ethnic Relations: An Analysis of U.S. American Concepts in the Japanese Context." Graduate Journal of Social Science. 2-1: 75-110.

Selected Presentations: 2005. Isao Takei, Rogelio Saenz and Jing Li. "Cost of Being a Mexican Immigrant and Being a Mexican Non-Citizen." Paper presented at the Population Association of America annual meeting, Philadelphia, PA.

2005. Wesley R. Dean, Isao Takei, William Alex. McIntosh, H. Morgan Scott and Kerry Barling. "Predicting the Antibiotic Behavior of Beef Feedlot Operators." Paper presented at the Rural Sociological Society annual meeting, Tampa, FL.

2005. Isao Takei, Rogelio Saenz and Jing Li. "Cost of Being a Mexican Immigrant and Being a Mexican Non-Citizen: Some Empirical Evidence from Interaction Tests." Paper presented at the American Sociological Association annual meeting, Philadelphia, PA. 